Statistical Summary of Selected Physical, Chemical, and Toxicity Characteristics and Estimates of Annual Constituent Loads in Urban Stormwater, Maricopa County, Arizona

Water-Resources Investigations Report 01-4088 Prepared in cooperation with the FLOOD CONTROL DISTRICT OF MARICOPA COUNTY
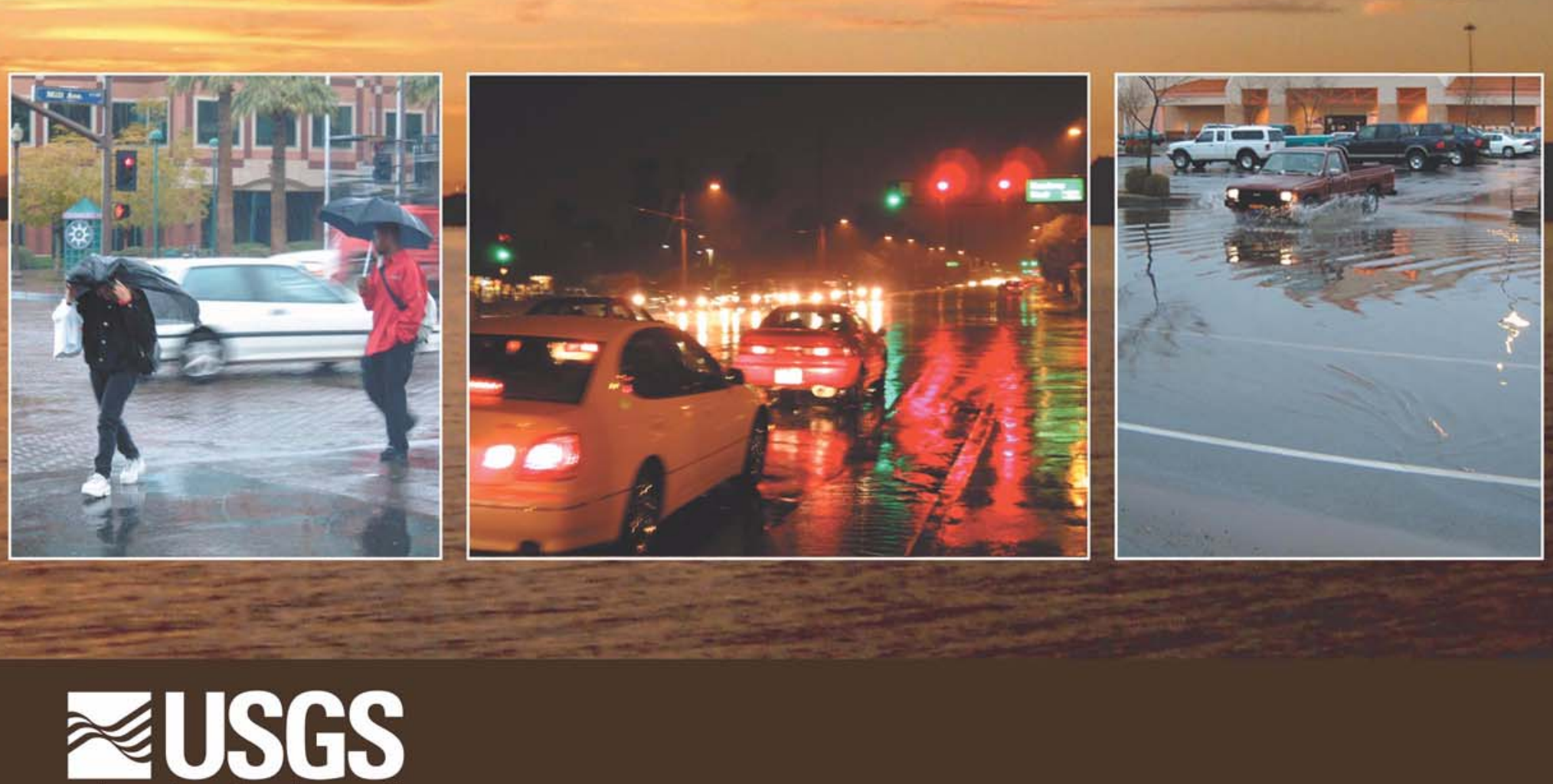


\section{Statistical Summary of Selected Physical, Chemical, and Toxicity Characteristics and Estimates of Annual Constituent Loads in Urban Stormwater, Maricopa County, Arizona}

Water-Resources Investigations Report 01—4088

Prepared in cooperation with the

FLOOD CONTROL DISTRICT OF MARICOPA COUNTY 


\section{U.S. DEPARTMENT OF THE INTERIOR \\ GALE A. NORTON, Secretary}

U.S. GEOLOGICAL SURVEY

Charles G. Groat, Director

The use of firm, trade, and brand names in this report is for identification purposes only and does not constitute endorsement by the U.S. Geological Survey.

For additional information write to:

District Chief

U.S. Geological Survey

Water Resources Division

520 N. Park Avenue, Suite 221

Tucson, AZ 85719-5035
Copies of this report can be purchased from:

U.S. Geological Survey

Information Services

Box 25286

Federal Center

Denver, C0 80225-0046

Information regarding research and data-collection programs of the U.S. Geological Survey is available on the Internet via the World Wide Web. You may connect to the home page for the Arizona District Office using the URL http://az.water.usgs.gov. 


\section{CONTENTS}

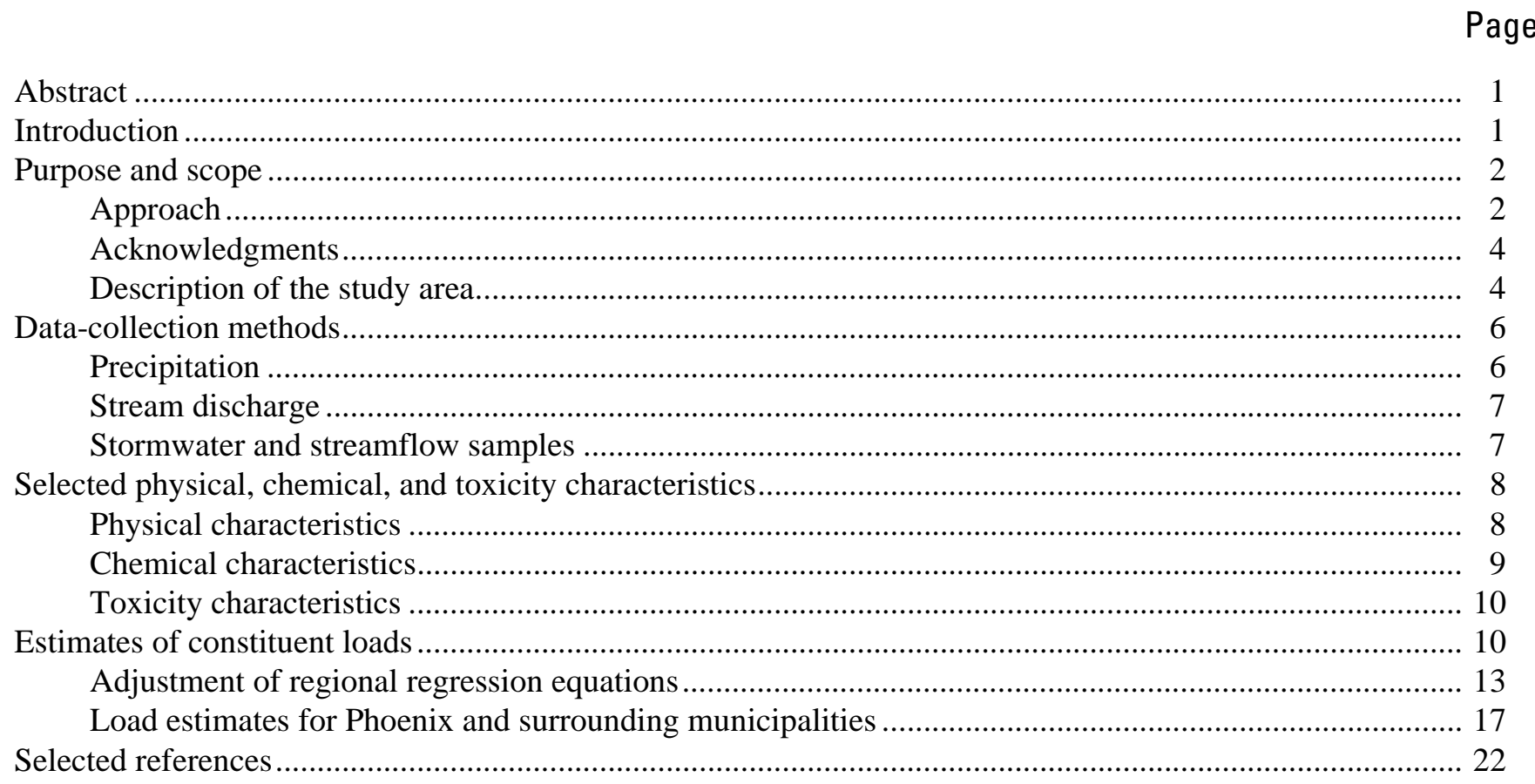

Selected water-quality and toxicity data for flow-weighted composite and instantaneous samples of stormwater and streamflow

\section{FIGURES}

1. Map showing study area and stormwater-monitoring stations, Maricopa County, Arizona... 


\section{TABLES}

1. Mean monthly precipitation and mean monthly maximum and minimum temperatures,

Sky Harbor International Airport, Phoenix, Arizona

2. Characteristics of seasonal storms that exceeded 0.1 inch of precipitation in the metropolitan Phoenix area, Arizona

3. Drainage area, land use, and impervious area for stormwater- and streamflow-monitoring stations, Maricopa County, Arizona

4. Summary statistics for selected properties and event-mean constituent concentrations measured in stormwater from urban drainage basins monitored by the U.S. Geological Survey and Flood Control District of Maricopa County, Arizona

5. Toxicity data, Maricopa County, Arizona

6. Comparison of predicted constituent loads with observed constituent loads in stormwater and comparison of predicted volume of storm runoff with observed volume of storm runoff, Maricopa County, Arizona

7. Explanatory variables that were correlated with observed constituent loads and volume of storm runoff at a level of 10 percent, Maricopa County, Arizona

8. Calibration-error statistics for adjusting regional regression equations with local data, Maricopa County, Arizona

9. Summary of regression equations selected for estimating storm-runoff constituent loads and volumes for Phoenix and surrounding municipalities

10. Summary statistics of regression equations for estimating storm-runoff constituent loads and volumes for Phoenix and surrounding municipalities

11. Estimated mean summer constituent loads for Phoenix and surrounding municipalities ................... 18

12. Estimated mean winter constituent loads for Phoenix and surrounding municipalities.................... 19

13. Estimated mean spring constituent loads for Phoenix and surrounding municipalities ..................... 19

14. Estimated mean annual constituent loads for Phoenix and surrounding municipalities .................... 20

15. Estimated mean seasonal and annual volumes of runoff for Phoenix and surrounding municipalities

16. Summary data

\section{CONVERSION FACTORS}

\begin{tabular}{rcl}
\hline Multiply & By & To obtain \\
\hline inch (in.) & 25.4 & millimeter \\
inch (in.) & 2.54 & centimeter \\
foot $(\mathrm{ft})$ & 0.3048 & meter \\
square ${\text { mile }\left(\mathrm{mi}^{2}\right)}_{\text {cubic foot per second }\left(\mathrm{ft}^{3} / \mathrm{s}\right)}$ & 2.590 & square kilometer \\
acre & .0283 & cubic meter per second \\
pound (lb) & 0.4047 & hectare \\
\hline
\end{tabular}

Temperature in degrees Fahrenheit $\left({ }^{\circ} \mathrm{F}\right)$ may be converted to degrees Celsius $\left({ }^{\circ} \mathrm{C}\right)$ as follows:

$$
{ }^{\circ} \mathrm{C}=\left({ }^{\circ} \mathrm{F}-32\right) / 1.8
$$




\section{ABBREVIATED WATER-QUALITY UNITS}

Chemical concentrations are given only in metric units. Chemical concentration in water is given in milligrams per liter $(\mathrm{mg} / \mathrm{L})$ or micrograms per liter $(\mu \mathrm{g} / \mathrm{L})$. Milligrams per liter is a unit expressing the solute mass per unit volume (liter) of water. One thousand micrograms per liter is equivalent to 1 milligram per liter. For concentrations less than 7,000 milligrams per liter, the numerical value is about the same as for concentrations in parts per million (ppm). Specific conductance is given in microsiemens per centimeter $(\mu \mathrm{S} / \mathrm{cm})$ at $25^{\circ} \mathrm{C}$.

\section{VERTICAL DATUM}

Sea level: In this report, "sea level" refers to the National Geodetic Vertical Datum of 1929 (NGVD of 1929)—a geodetic datum derived from a general adjustment of the first-order level nets of both the United States and Canada, formerly called Sea Level Datum of 1929.

\section{DEFINITION OF ABBREVIATIONS AND ACRONYMS}

CD Total recoverable cadmium in storm-runoff load, in pounds, or in storm-runoff mean concentration, in micorgrams per liter.

COD Chemical oxygen demand in storm-runoff load, in pounds, or in storm-runoff mean concentration, in milligrams per liter.

CU Total recoverable copper in storm-runoff load, in pounds, or in storm-runoff mean concentration, in micrograms per liter.

DA Total contributing drainage area.

DP Dissolved phosphorus in storm-runoff load, in pounds, or in storm-runoff mean concentration, in milligrams per liter.

DRN Duration of each storm, in minutes, for storm-runoff load and mean-concentration models.

DS Dissolved solids in storm-runoff load, in pounds, or in storm-runoff mean concentration, in milligrams per liter.

FCDMC Flood Control District of Maricopa County.

GIS Geographic information system.

IA Impervious area, as a percentage of total contributing drainage area.

LUC Commercial land use, as a percentage of total contributing drainage area.

LUI Industrial land use, as a percentage of total contributing drainage area.

LUN Undeveloped land use, as a percentage of total contributing drainage area.

LUR Residential land use, as a percentage of total contributing drainage area.

MAP Model-adjustment procedure.

NPDES National Pollutant Discharge Elimination System.

PB Total recoverable lead in storm-runoff load, in pounds, or in storm-runoff mean concentration, in micrograms per liter.

RUN Storm-runoff volume, in cubic feet.

SS Suspended solids in storm-runoff load, in pounds, or in storm-runoff mean concentration, in milligrams per liter.

TKN Ammonia plus organic nitrogen (total as nitrogen in storm-runoff load, in pounds, or in storm-runoff mean concentration, in milligrams per liter.

TN Total nitrogen in storm-runoff load, in pounds, or in storm-runoff mean concentration, in milligrams per liter as nitrogen.

TP Total phosphorus in storm-runoff load, in pounds, or in storm-runoff mean concentration, in milligrams per liter as phosphorus.

TRN Total storm rainfall, in inches.

USEPA U.S. Environmental Protection Agency.

USGS U.S. Geological Survey.

ZN Total recoverable zinc in storm-runoff load, in pounds, or in storm-runoff mean concentration, in micrograms per liter. 


\title{
Statistical Summary of Selected Physical, Chemical, and Toxicity Characteristics and Estimates of Constituent Loads in Urban Stormwater, Maricopa County, Arizona
}

\author{
By Kenneth D. Fossum, Christie M. O’Day, Barbara J. Wilson, and Jim E. Monical
}

\begin{abstract}
Stormwater and streamflow in Maricopa County were monitored to (1) describe the physical, chemical, and toxicity characteristics of stormwater from areas having different land uses, (2) describe the physical, chemical, and toxicity characteristics of streamflow from areas that receive urban stormwater, and (3) estimate constituent loads in stormwater. Urban stormwater and streamflow had similar ranges in most constituent concentrations. The mean concentration of dissolved solids in urban stormwater was lower than in streamflow from the Salt River and Indian Bend Wash. Urban stormwater, however, had a greater chemical oxygen demand and higher concentrations of most nutrients.

Mean seasonal loads and mean annual loads of 11 constituents and volumes of runoff were estimated for municipalities in the metropolitan Phoenix area, Arizona, by adjusting regional regression equations of loads. This adjustment procedure uses the original regional regression equation and additional explanatory variables that were not included in the original equation. The adjusted equations had standard errors that ranged from 161 to 196 percent. The large standard errors of the prediction result from the large variability of the constituent concentration data used in the regression analysis.

Adjustment procedures produced unsatisfactory results for nine of the regressions-suspended solids, dissolved solids, total phosphorus, dissolved phosphorus, total recoverable cadmium, total recoverable copper, total recoverable lead, total recoverable zinc, and storm runoff. These equations had no consistent direction of bias and no other additional explanatory variables correlated with the observed loads. A stepwise-multiple regression or a three-variable regression (total storm rainfall, drainage area, and impervious area) and local data were used to develop local regression equations for these nine constituents. These equations had standard errors from 15 to 183 percent.

\section{INTRODUCTION}

The U.S. Environmental Protection Agency (USEPA), under section 402(p) of the Water Quality Act of 1987, requires municipalities with populations of more than 100,000 to obtain National Pollutant Discharge Elimination System (NPDES) permits for urban stormwater discharge. This regulation is intended to minimize pollutant loadings from urbanized areas and preserve the quality of streams that receive stormwater. To comply with the conditions of a permit, a municipality must monitor the chemistry of stormwater from areas having residential, commercial, and industrial land uses and estimate annual pollutant loads of selected constituents that are discharged in stormwater and runoff. These estimates will be used by the municipalities to evaluate the magnitude of pollutant loadings and the efficiency of management strategies that are intended to reduce pollutant loads.
\end{abstract}


Phoenix, Mesa, Tempe, Scottsdale, Glendale, and unincorporated Maricopa County (fig. 1) each have populations of more than 100,000. These municipalities, and other contiguous municipalities with populations of less than 100,000, constitute the metropolitan Phoenix area. Most stormwater in the Phoenix area is routed into drainage channels, which are tributary to ephemeral streams including the Gila, Salt, New, and Agua Fria Rivers. Data on the types and amounts of constituents discharged in stormwater were needed by water-management agencies to design stormwater-management strategies and to assess the effects of stormwater on the water resources of Maricopa County. The U.S. Geological Survey (USGS), in cooperation with the Flood Control District of Maricopa County (FCDMC), monitored stormwater from October 1991 to October 1998 in Phoenix, Tempe, and Glendale. Stormwater was monitored to (1) characterize the chemistry of stormwater and compute annual loadings of selected constituents from drainage basins with urban land uses, and (2) characterize the chemistry of streamflow from two ephemeral streams that receive urban stormwater.

\section{PURPOSE AND SCOPE}

This report presents physical, chemical, and toxicity characteristics of stormwater from drainage basins with residential, commercial, light industrial, heavy industrial, and undeveloped land uses and characteristics of streamflow from the Salt River and Indian Bend Wash. Estimates of mean seasonal and mean annual constituent loads and volumes of runoff are presented for municipalities in the metropolitan Phoenix area.

Estimates of mean seasonal and mean annual constituent loads are reported for chemical oxygen demand, suspended solids, dissolved solids, total nitrogen, total ammonia plus organic nitrogen, total phosphorus, dissolved phosphorus, total recoverable cadmium, total recoverable copper, total recoverable lead, and total recoverable zinc. This analysis includes data collected from October 1991 to October 1998 from six urban drainage basins sampled by the USGS and nine urban drainage basins sampled by the FCDMC.

\section{Approach}

Drainage basins with a predominant land use were monitored so that stormwater from areas with different land uses could be characterized. The duration of storm flow typically is short (1-2 hours) and makes sampling difficult. Stormwater-gaging stations were instrumented with equipment that allowed remote monitoring of rainfall and stream discharge and connected by phone lines, so that field crews could get to the sites and manually collect grab samples before runoff stopped. Stormwater-gaging stations were instrumented with automatic samplers to collect flow-weighted discrete samples representative of the event and to reduce personnel requirements for the study. Six drainage basins were monitored by the USGS. The FCDMC monitored nine urban drainage basins using a similar approach.

Load estimates were made by adjusting regional regression equations (Driver and Tasker, 1990) for local applications. Land-use data and a geographic information system (GIS) were used with the adjusted equations to estimate constituent loads and volume of runoff from each municipality.

Monitoring stations were installed in drainage basins with residential, commercial, light industrial, heavy industrial, and undeveloped land uses. Drainage basins with a predominant land use were selected so that stormwater from different land uses could be characterized. Additional criteria for the selection of drainage basins included (1) an outfall at which a stage-discharge rating could be developed so that stream discharge could be computed, (2) definite drainage-basin boundaries so that drainage-basin characteristics could be computed, and (3) a contributing area of less than 1,920 acres so that data would be consistent with data used to develop regional regression equations (Driver and Tasker, 1990, table 4). 


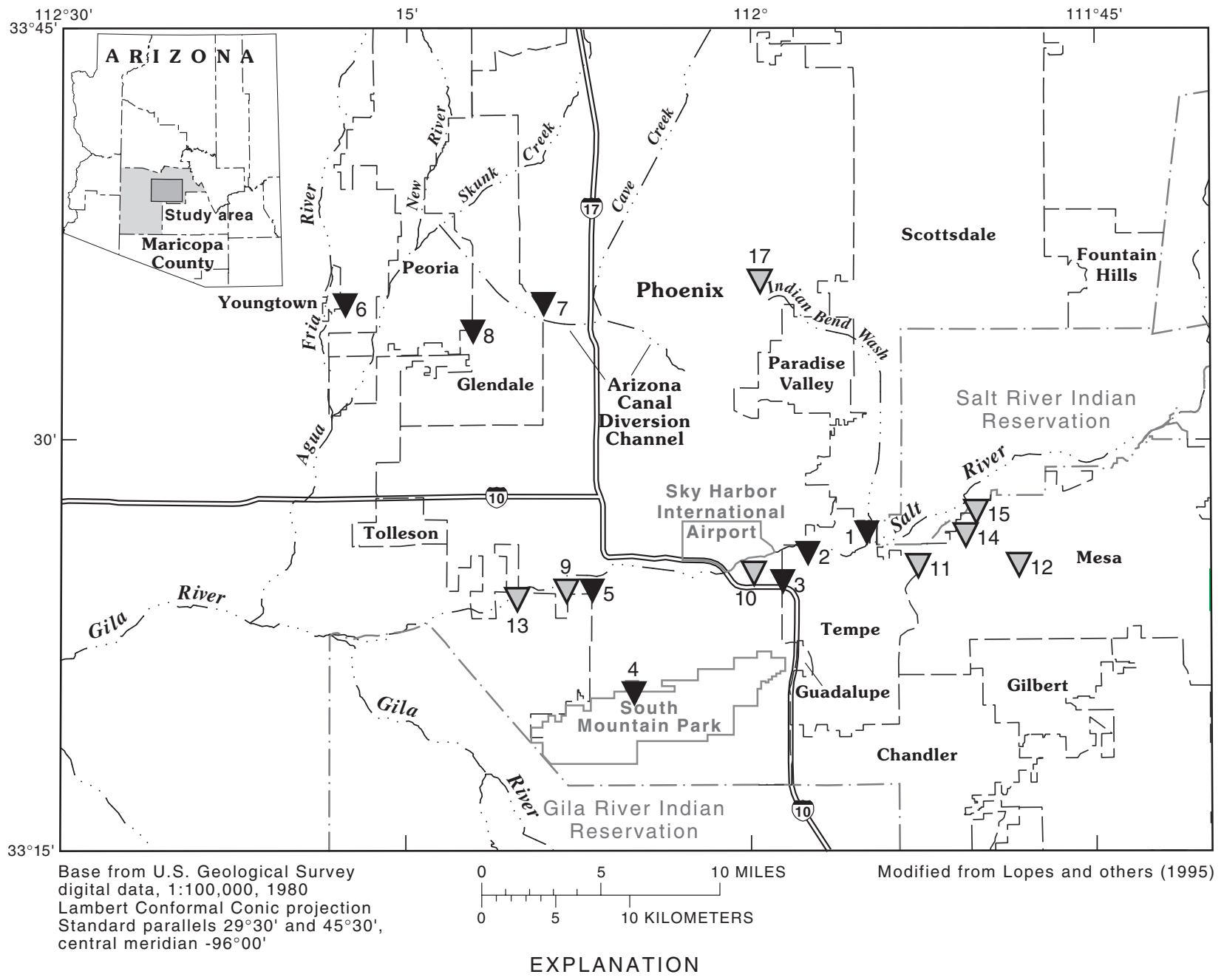

STORMWATER-MONITORING STATIONS - Number is site identifier

$\nabla 7$ U.S. Geological Survey

$\nabla 12$ Flood Control District of Maricopa County

$\begin{array}{cl}\text { Site } & \text { Station number } \\ 1 & 09512162 \\ 2 & 09512165 \\ 3 & 09512184 \\ 4 & 09512200 \\ 5 & 09512403 \\ 6 & 09513700 \\ 7 & 09513885 \\ 8 & 09513925 \\ 9 & 332333112080301 \\ 10 & 332409111594101 \\ 11 & 332429111522701 \\ 12 & 332430111461401 \\ 13 & 332430112101001 \\ 14 & 332540111494601 \\ 15 & 332622111461401 \\ 16 & 332721111444101 \\ 17 & 333557111594201\end{array}$

Station name

Indian Bend Wash at Curry Road, at Tempe

Salt River at Priest Drive, near Phoenix

Box culvert at 48th Street drain

Salt River tributary in South Mountain Park, at Phoenix

27th Avenue at Salt River

Agua Fria River tributary at Youngtown

43rd Avenue and Peoria Avenue

67th Avenue and Olive Avenue

35th Avenue at Salt River

40th Street at Salt River

Broadway Road and Dobson Road

Broadway Road and Lindsay Road

67th Avenue at Salt River

Horne and 6th Street

Horne and Grandview Street

Fighter Aces Drive, north of McKellips Road

40th Street at Indian Bend Wash

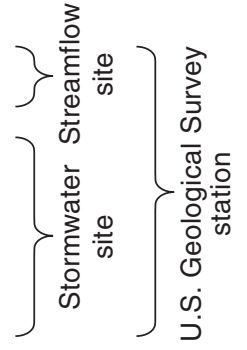

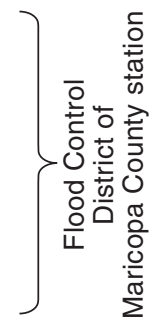

Figure 1. Study area and stormwater-monitoring stations, Maricopa County, Arizona. 


\section{Acknowledgments}

Marilyn DeRosa and Dave Gardner, FCDMC, provided support and cooperation throughout the study. Carol Davis, formerly with FCDMC, obtained permits to install the monitoring stations. Jess and Sons allowed access through their property at 27th Avenue.

\section{Description of the Study Area}

The study area is in a broad, flat basin in south-central Arizona (fig. 1). The basin is about 1,000 to 1,300 ft above sea level and slopes downward from east to west. The highest peak in the surrounding mountains (North Mountain, Squaw Peak, Camelback, and South Mountain) is about 2,700 ft above sea level in South Mountain Park. The metropolitan Phoenix area is about $957 \mathrm{mi}^{2}$ and includes the cities of Chandler, Gilbert, Glendale, Guadalupe, Mesa, Paradise Valley, Peoria, Phoenix, Scottsdale, Tempe, Tolleson, and Youngtown.

The combined population of municipalities included in this study is 2,501,685 (Maricopa Association of Governments, 1998), which is about 89 percent of the total population of Maricopa County. Residential and open spaces are the most abundant land-use types and constitute about 62 and 18 percent of the metropolitan Phoenix area, respectively (Maricopa Association of Governments, 1998). The remaining 20 percent includes other land uses such as commercial and industrial, and land used for parks and schools.

Maricopa County is in the northern Sonoran Desert climatic zone. The maximum mean monthly temperature is $105.3^{\circ} \mathrm{F}$, and the minimum mean monthly temperature is $41.6^{\circ} \mathrm{F}$ (National Oceanic and Atmospheric Administration, 1998; table 1, this report). Mean annual rainfall, for years 1954-90, at Sky Harbor International Airport was $7.66 \mathrm{in}$. Most of the annual rainfall occurs from two weather patterns that have distinct characteristics (table 2). About 40 percent of the annual rainfall occurs between July and October from subtropical monsoons that originate from the Gulf of Mexico and Gulf of California and typically are short-duration, high-intensity thunderstorms. About 50 percent of the annual rainfall occurs between November and March from cold fronts that originate in the Gulf of Alaska and typically are long-duration, low-intensity storms. The remaining 10 percent of the annual rainfall occurs between April and June and could be the result of either type of weather pattern.

Table 1. Mean monthly precipitation and mean monthly maximum and minimum temperatures, Sky Harbor International Airport, Phoenix, Arizona

[Period of data, 1968-98. Data from National Oceanic and Atmospheric Administration, 1998]

\begin{tabular}{|c|c|c|c|c|c|c|c|}
\hline \multirow[b]{3}{*}{ Month } & \multicolumn{3}{|c|}{ Climatic variable } & \multirow[b]{3}{*}{ Month } & \multicolumn{3}{|c|}{ Climatic variable } \\
\hline & \multirow{2}{*}{$\begin{array}{c}\text { Mean } \\
\text { monthly } \\
\text { precipi- } \\
\text { tation, } \\
\text { in inches }\end{array}$} & \multicolumn{2}{|c|}{$\begin{array}{l}\text { Mean monthly temperature, } \\
\text { in degrees Fahrenheit }\end{array}$} & & \multirow{2}{*}{$\begin{array}{c}\text { Mean } \\
\text { monthly } \\
\text { precipi- } \\
\text { tation, } \\
\text { in inches }\end{array}$} & \multicolumn{2}{|c|}{$\begin{array}{l}\text { Mean monthly temperature, } \\
\text { in degrees Fahrenheit }\end{array}$} \\
\hline & & Maximum & Minimum & & & Maximum & Minimum \\
\hline January & 0.67 & 65.9 & 41.6 & July & 0.83 & 105.3 & 80.7 \\
\hline February & .68 & 70.7 & 44.9 & August & .96 & 103.2 & 79.4 \\
\hline March & .88 & 75.5 & 49.1 & September & .86 & 98.5 & 72.8 \\
\hline April & .22 & 84.2 & 55.8 & October & .65 & 88.1 & 61.1 \\
\hline May & .12 & 93.2 & 64.2 & November & .66 & 74.5 & 48.7 \\
\hline June & .13 & 102.9 & 72.9 & December & 1.00 & 66.2 & 42.2 \\
\hline
\end{tabular}


Table 2. Characteristics of seasonal storms that exceeded 0.1 inch of precipitation in the metropolitan Phoenix area, Arizona

[Values were calculated using data from Sky Harbor International Airport, 1954-90. Storm separation is the criterion used to differentiate separate storms. Storms were considered separate when the number of hours without rainfall was equal to or greater than the storm separation]

\begin{tabular}{|c|c|c|c|c|c|c|c|c|c|c|c|c|}
\hline \multirow[b]{2}{*}{ Type of storm } & \multirow{2}{*}{$\begin{array}{l}\text { Months of } \\
\text { season }\end{array}$} & \multirow{2}{*}{$\begin{array}{c}\text { Storm } \\
\text { separation, } \\
\text { in hours }\end{array}$} & \multicolumn{2}{|c|}{$\begin{array}{c}\text { Storm } \\
\text { rainfall, } \\
\text { in inches }{ }^{1}\end{array}$} & \multirow{2}{*}{$\begin{array}{c}\text { Mean } \\
\text { storm } \\
\text { rainfall, } \\
\text { in } \\
\text { inches }\end{array}$} & \multirow{2}{*}{$\begin{array}{r}\text { Standard } \\
\text { deviation, } \\
\text { in inches }\end{array}$} & \multicolumn{2}{|c|}{$\begin{array}{l}\text { Storm } \\
\text { duration, } \\
\text { in hours }\end{array}$} & \multirow{2}{*}{$\begin{array}{c}\text { Mean } \\
\text { storm } \\
\text { duration, } \\
\text { in hours }\end{array}$} & \multicolumn{2}{|c|}{$\begin{array}{c}\text { Number of } \\
\text { storms }^{1}\end{array}$} & \multirow{2}{*}{$\begin{array}{c}\text { Mean } \\
\text { number } \\
\text { of storms }\end{array}$} \\
\hline & & & From & To & & & From & To & & From & To & \\
\hline Summer monsoon & July-October & 6 & 0.44 & 0.46 & 0.46 & 0.43 & 4.36 & 5.82 & 5.06 & 7 & 6 & 7 \\
\hline Winter cold front & November-March & 12 & .41 & .47 & .46 & .39 & 10.6 & 17.06 & 14.1 & 8 & 7 & 7 \\
\hline $\begin{array}{c}\text { Either cold front } \\
\text { or monsoon }\end{array}$ & April-June & 9 & .32 & .38 & .36 & .32 & 5.44 & 10.10 & 8.56 & 2 & 2 & 2 \\
\hline
\end{tabular}

${ }^{1}$ Values are ranges when storm separation is varied by 50 percent.

Urban stormwater was monitored at six drainage basins in Maricopa County by the USGS (water years 1991-98). These basins were chosen on the basis that they consist mainly of a single land use. Two basins were residential land use, one was commercial land use, one was light industrial land use, one was heavy industrial land use, and one was undeveloped land use. The basins ranged from 3.4 to 1,120 acres in size and from 1 to 94 percent in impervious area (table 3).

Table 3. Drainage area, land use, and impervious area for stormwater- and streamflow-monitoring stations, Maricopa County, Arizona

[South Mountain drainage area has about 1 percent roads, which were not categorized into a particular land use. Station numbers with a 0951 prefix were monitored by the U.S. Geological Survey; station numbers with a 33 prefix were monitored by the Flood Control District of Maricopa County. NA, not available]

\begin{tabular}{|c|c|c|c|c|c|c|c|c|}
\hline \multirow[b]{2}{*}{$\begin{array}{l}\text { Station } \\
\text { number }\end{array}$} & \multirow[b]{2}{*}{ Station name } & \multirow{2}{*}{$\begin{array}{c}\text { Area of } \\
\text { drainage } \\
\text { basin, } \\
\text { in acres }\end{array}$} & \multicolumn{5}{|c|}{ Land use, in percent } & \multirow{2}{*}{$\begin{array}{c}\text { Imper- } \\
\text { vious } \\
\text { area, } \\
\text { in percent }\end{array}$} \\
\hline & & & $\begin{array}{c}\text { Resi- } \\
\text { dential }\end{array}$ & $\begin{array}{l}\text { Light } \\
\text { industry }\end{array}$ & $\begin{array}{l}\text { Heavy } \\
\text { industry }\end{array}$ & $\begin{array}{l}\text { Com- } \\
\text { mercial }\end{array}$ & $\begin{array}{l}\text { Unde- } \\
\text { veloped }\end{array}$ & \\
\hline \multicolumn{9}{|c|}{ Stormwater-monitoring stations } \\
\hline 09512184 & Box culvert at 48th Street drain & 39 & 0 & 85 & 0 & 8 & 7 & 80 \\
\hline 09512200 & $\begin{array}{l}\text { Salt River tributary in South } \\
\text { Mountain Park, at Phoenix }\end{array}$ & 1,120 & 0 & 0 & 0 & 0 & 99 & 1 \\
\hline 09512403 & 27th Avenue at Salt River & 45 & 6 & 0 & 94 & 0 & 0 & 15 \\
\hline 09513700 & $\begin{array}{l}\text { Agua Fria River tributary at } \\
\text { Youngtown }\end{array}$ & 81 & 90 & 0 & 0 & 10 & 0 & 33 \\
\hline 09513885 & 43rd Avenue and Peoria Avenue & 3.4 & 0 & 0 & 0 & 97 & 3 & 94 \\
\hline 09513925 & 67th Avenue and Olive Avenue & 17.8 & 100 & 0 & 0 & 0 & 0 & 60 \\
\hline 333557111594201 & 40th Street at Indian Bend Wash & 609 & 78 & 0 & 0 & 11 & 11 & 37 \\
\hline 332333112080301 & 35th Avenue at Salt River & 1,363 & 21 & 24 & 18 & 18 & 19 & 54 \\
\hline 332409111594101 & 40th Street at Salt River & 120 & 0 & 0 & 100 & 0 & 0 & 74 \\
\hline 332430112101001 & 67th Avenue at Salt River & 4,740 & 13 & 26 & 0 & 0 & 61 & 15 \\
\hline 332540111494601 & Horne and 6th Street & 193 & 100 & 0 & 0 & 0 & 0 & 63 \\
\hline 332430111461401 & Broadway Road and Lindsay Road & 145 & 98 & 0 & 0 & 0 & 2 & 26 \\
\hline 332721111444101 & $\begin{array}{l}\text { Fighter Aces Drive north of } \\
\text { McKellips Road }\end{array}$ & 171 & 0 & 100 & 0 & 0 & 0 & 65 \\
\hline 332622111461401 & Horne and Grandview Street & 113 & 100 & 0 & 0 & 0 & 0 & 51 \\
\hline 332429111522701 & Broadway Road and Dobson Road & 63 & 0 & 0 & 0 & 100 & 0 & 89 \\
\hline \multicolumn{9}{|c|}{ Streamflow-monitoring stations } \\
\hline 09512162 & $\begin{array}{l}\text { Indian Bend Wash at Curry Road, } \\
\text { at Tempe }\end{array}$ & 52,480 & NA & NA & NA & NA & NA & NA \\
\hline 09512165 & $\begin{array}{l}\text { Salt River at Priest Drive, near } \\
\text { Phoenix }\end{array}$ & $8,565,000$ & NA & NA & NA & NA & NA & NA \\
\hline
\end{tabular}


Urban stormwater also was monitored at four drainage basins in the city of Phoenix and five drainage basins in the city of Mesa by the FCDMC (water years 1991-98). Drainage basins were 63 to 4,740 acres and consisted of homogenous and mixed land uses (table 3). Impervious areas were not measured in drainage basins within the metropolitan Phoenix area, but the percentage of impervious area was estimated for each land-use type (Flood Control District of Maricopa County, 1993). The impervious area for each land-use type was: very low-density residential, 15 percent; low-density residential, 25 percent; medium-density residential, 45 percent; multiple-family residential, 65 percent; industrial, 75 percent; and commercial, 90 percent. Comparison of these percentages with the percentage of impervious areas measured at drainage basins monitored by the USGS indicates that these estimated values are accurate.

Streamflow was monitored at Indian Bend Wash at Curry Road, at Tempe (09512162) and Salt River at Priest Drive, near Phoenix (09512165; table 3). Station 09512162 collects stormwater from many outfalls from Paradise Valley, Scottsdale, and Tempe. Runoff at this location discharges into the Salt River. Streamflow-gaging station 09512165 is in the central part of the metropolitan Phoenix area, and less than about 5 percent of the drainage area is urbanized. The Salt River is ephemeral and typically flows only during large storms in the metropolitan Phoenix area or when dams upstream from Maricopa County release water. Most streamflow samples were collected during the flood of 1993 when water was released from dams on the Verde and Salt Rivers and streamflow reached a maximum of 129,000 $\mathrm{ft}^{3} / \mathrm{s}$ on January 8, 1993, as recorded at streamflow-gaging station Salt River at Alma School Road near Mesa (09512060, Smith and others, 1994).

\section{DATA-COLLECTION METHODS}

Storm-runoff data, precipitation data, and water samples were monitored and collected by the USGS using the following equipment:

- Campbell Scientific Instruments, Inc., CR10 datalogger, and SM192 storage module,

- Sierra-Misco Environment Ltd., Model 2500 tipping-bucket rain gage,

- $\quad$ Druck PDCR 940 pressure transducer,

- Conoflow and pressure-regulator system,

- Corning Checkmate 90 meter,

- Isco, Inc., Model 3700 automatic-pumping sampler, and

- Motorola MC310 cellular telephone or telephone line.

Measurement of streamflow stage and precipitation and the activation of the automatic-pumping sampler were managed by the CR10 datalogger. The datalogger was programmed to record gage height and precipitation, calculate stream discharge, and activate the automatic-pumping sampler when a specified volume of water had been discharged from the drainage basin. The datalogger also initiated a telephone call to project personnel when precipitation or discharge was measured so personnel could make manual discharge measurements for ratings verification and manually collect the grab portion of the water sample during runoff. Data were recorded at 1-minute intervals when either rainfall or stream discharge was being measured. During dry periods, the data were recorded once a day (at midnight).

\section{Precipitation}

Precipitation was measured at all urban monitoring stations using tipping-bucket rain gages. The rain gages transmitted electrical pulses to the dataloggers each time 0.01 in. of rainfall was measured. Rainfall intensity was then measured by calculating the number of pulses received by the datalogger each minute. Accumulated rainfall was calculated by summing the number of pulses for the duration of each storm. The rain gages generally were cleaned and calibrated twice a year. 


\section{Stream Discharge}

Stream discharge is computed from rating curves that define the relation between gage height (the watersurface elevation of the stream) and an associated discharge. Gage height was measured at six urban drainage basins monitored by the USGS using a Conoflow and pressure-regulator system. The Conoflow and pressure regulator maintain a constant rate of nitrogen flowing through a tube that extends from the gaging station to an orifice at the bottom of the channel or culvert. The pressure required to maintain a constant flow rate through the tube increases as stage increases. Pressure in the tube was measured by a pressure transducer, which was calibrated to within $0.02 \mathrm{ft}$ and placed 3 to $5 \mathrm{ft}$ underground to reduce effects of ambient temperature on measurements. The exception was at 27th Avenue at Salt River (09512403) where the transducer was placed in the culvert and thermally insulated. Gage height was measured continuously by a float and tape system at Indian Bend Wash at Curry Road, at Tempe (09512162) and intermittently measured manually using a wire-weight gage at Salt River at Priest Drive, near Phoenix (09512165).

Stage-discharge ratings for five of the six stormwater monitoring stations originally were developed on the basis of channel geometry and slope using the slope-conveyance method (Kennedy, 1984). The ratings were refined later by making manual discharge measurements at each of the stations. Instantaneous discharges at stormwater monitoring stations were computed by programming the datalogger with a log-normal regression equation that was fitted to the stage-discharge rating of each station. Stream-discharge volumes were computed by multiplying the mean of two consecutive instantaneous discharge measurements by 60 seconds to obtain the mean volume of stream discharge during that 1-minute interval. The mean volumes were summed to obtain the total volume of runoff.

A stage-discharge rating based on historical recorded gage heights and instantaneous discharge measurements were used at Indian Bend Wash (period of record water years 1993-98) and South Mountain (period of record water years 1961-93) stations. Discharge measurements were made using either a Price pygmy meter or Price AA meter and the 0.6- depth or 0.2- and 0.8-depth wading method or bridge method (Rantz and others, 1982). Discharge measurements were made when streamflow samples were collected from the Salt River at Priest Drive and were used to verify developed stage-discharge ratings.

\section{Stormwater and Streamflow Samples}

Water samples were collected from urban drainage basins by automatic-pumping samplers and by manually collecting grab samples. Field measurements were made when grab samples were collected. The automaticpumping sampler is a portable, nonrefrigerated unit calibrated to pump a specified volume of stormwater per sample. Intakes are anchored to the streambed in the centroid of flow. Twenty-four Teflon-lined, 1-liter, polyethylene bottles were used to collect flow-weighted discrete samples that were pumped when a specified volume of water had discharged from the drainage basin past the measuring point. Samples were chilled to $4^{\circ} \mathrm{C}$ and transported to the Tempe field office for processing. The specific electrical conductance of each of the 24 discrete samples was measured before the samples were composited. The samples were poured into a Teflon-lined, stainless-steel churn splitter to split the composite sample into bottles required for each chemical analysis. In addition to whole-water samples, samples for the determination of dissolved constituents were collected and were filtered using 0.45 -micron effective pore-size cellulose filters. Preservatives then were added to sample bottles as required. All components of the sampling equipment that came into contact with sample water were constructed of either glass, Teflon, or stainless steel, except for the silicon-rubber distribution hose in the automatic-pumping sampler. Equipment that was in contact with sample water was cleaned by washing with Liquinox followed by a rinse of tap water, a rinse of ultrapure methanol, and a final rinse of deionized water.

Field measurements of dissolved-oxygen concentration, $\mathrm{pH}$, specific electrical conductance, and temperature were measured when grab samples were collected. A Corning Checkmate 90 meter and electrodes were used for all field measurements, and the meter was calibrated using standard solutions before each measurement. 
Water samples were collected from Indian Bend Wash and the Salt River using the equal-width-increment with depth-integration method and by collecting grab samples. For the equal-width-increment method, depthintegrated samples were collected at equal distances perpendicular to the direction of flow during a period of time. Samples then were composited in a Teflon-lined churn splitter in the field to obtain a single sample that is representative of the stream at a specific time, generally the mean time between the begin time and the end time of the sample collection. The composite was transported back to the Tempe field office and processed as stated above. Field measurements were made in the same manner as those at the stormwater stations.

All samples were analyzed within appropriate holding times by the USGS National Water Quality Laboratory in Arvada, Colorado, or by the USGS Laboratory in Ocala, Florida. Alkalinity and acute toxicity were measured in the Tempe field office. Alkalinity was measured using the inflection-point method.

\section{SELECTED PHYSICAL, CHEMICAL, AND TOXICITY CHARACTERISTICS}

A total of 144 stormwater and streamflow samples was collected and analyzed from October 1991 to October 1998 to characterize stormwater from 6 drainage basins monitored by the USGS and streamflow from the Salt River and Indian Bend Wash. Two hundred-fifty samples were collected and analyzed from nine stations by the FCDMC. Concentrations measured in flow-weighted composite samples are the mean concentrations for a storm (event-mean concentration); whereas, concentrations measured in equal-width increments and manual-grab samples are concentrations at a specific point in time on the hydrograph (instantaneous concentrations). Unless stated otherwise, concentrations referred to in this report are event-mean concentrations. Quality-assurance and quality-control data are not presented in this report, but are available on request from the Tempe office of the USGS. Data presented at the end of this report were collected by the USGS from October 1995 to October 1998. Data collected prior to October 1995 were published in Lopes and others (1995) and in Fossum and Davis (1996). Data collected by the FCDMC (water years 1991-98) were used in all statistical and regression analyses and can be requested from the FCDMC.

\section{Physical Characteristics}

Stormwater and streamflow temperatures ranged from 8 to $32^{\circ} \mathrm{C}$, and the initial runoff from Agua Fria tributary at Youngtown, 43rd Avenue and Peoria Avenue at Phoenix, and 48th Street Drain at Tempe typically was black in color. Event-mean specific-conductance values from stormwater basins ranged from 17 to $894 \mu \mathrm{S} / \mathrm{cm}$, and instantaneous specific-conductance values of samples from streamflow basins ranged from 309 to $880 \mu \mathrm{S} / \mathrm{cm}$. In general, specific conductance decreased over the duration of storms, indicating that most soluble constituents were washed from exposed surfaces during the initial part of a storm or were diluted with additional rainfall. Specific conductance increased during some storms at 48th Street Drain and 27th Avenue (industrial sites). The increase could be due to runoff from areas in the drainage basin arriving at the stormwater-gaging station at different times.

Dissolved-solids concentrations from stormwater basins ranged from 15 to $1,290 \mathrm{mg} / \mathrm{L}$; about 75 percent of samples contained less than $160 \mathrm{mg} / \mathrm{L}$ (table 4). These low concentrations indicate that the drainage basins have few soluble solids, that stormwater had little effect on dissolving solids from exposed surfaces, or that the concentrations of soluble solids were diluted. Instantaneous dissolved-solids concentrations from streamflow basins ranged from 94 to $648 \mathrm{mg} / \mathrm{L}$; about 80 percent of the samples contained more than $200 \mathrm{mg} / \mathrm{L}$. These values indicate that the dissolved-solids concentrations of streamflow could be diluted by stormwater.

Suspended-solids concentrations from stormwater basins ranged from less than 1 to $4,800 \mathrm{mg} / \mathrm{L}$. Instantaneous suspended-solids concentrations from the Salt River and Indian Bend Wash ranged from 3 to 1,140 mg/L. The mean suspended-solids concentration for stormwater basins was $265 \mathrm{mg} / \mathrm{L}$, and the mean for streamflow basins was $173 \mathrm{mg} / \mathrm{L}$. The difference between stormwater and streamflow indicates that stormwater discharge could increase suspended-solids concentrations in streamflow. 
Table 4. Summary statistics for selected properties and event-mean constituent concentrations measured in stormwater from urban drainage basins monitored by the U.S. Geological Survey and Flood Control District of Maricopa County, Arizona

[Samples were collected between October 1991 and October 1998. Constituents are reported in milligrams per liter except for cadmium, copper, lead, and zinc, which are in micrograms per liter. <, less than]

\begin{tabular}{lcccccc}
\hline \multicolumn{1}{c}{ Property or constituent } & Maximum & Minimum & Mean & $\begin{array}{c}\text { Standard } \\
\text { deviation }\end{array}$ & $\begin{array}{c}\text { Number } \\
\text { of samples }\end{array}$ & $\begin{array}{c}\text { Number of } \\
\text { concentrations less } \\
\text { than detection limit }\end{array}$ \\
\hline Chemical oxygen demand & 21,000 & $<10$ & 256 & 1,168 & 344 & 8 \\
Suspended solids & 4,800 & $<1$ & 265 & 472 & 342 & 6 \\
Dissolved solids & 1,290 & 15 & 149 & 136 & 342 & 0 \\
Nitrogen, total & 31.6 & $<1.5$ & 5.24 & 3.80 & 295 & 2 \\
Nitrogen, ammonia plus & 18.8 & $<.5$ & 3.54 & 2.87 & 224 & 16 \\
$\quad$ organic, total & 10 & $<.05$ & .88 & 1.10 & 342 & 3 \\
Phosphorus, total & 2.6 & $<.02$ & .38 & .35 & 336 & 11 \\
Phosphorus, dissolved & 23 & $<.2$ & 2.26 & 2.82 & 351 & 225 \\
Cadmium, total recoverable & 1,060 & $<5$ & 71.1 & 108 & 344 & 102 \\
Copper, total recoverable & 1,420 & $<5$ & 69.2 & 134 & 349 & 113 \\
Lead, total recoverable & 1,860 & $<10$ & 279 & 290 & 351 & 31 \\
Zinc, total recoverable & & & & & & \\
\hline
\end{tabular}

\section{Chemical Characteristics}

Values of constituent concentrations commonly varied by an order of magnitude among the drainage basins and are log-normally distributed. Stormwater and streamflow had $\mathrm{pH}$ values from 5.7 to 9.3 , which are typical values for most river waters (Hem, 1985, p. 64). Acid-neutralizing capacity values ranged from 7 to $363 \mathrm{mg} / \mathrm{L}$ as calcium carbonate, and alkalinity values ranged from 5 to $142 \mathrm{mg} / \mathrm{L}$ as calcium carbonate. For all samples, acid-neutralizing capacity exceeded or was about equal to the alkalinity. Dissolved-oxygen concentrations ranged from 4.8 to $12.7 \mathrm{mg} / \mathrm{L}$, because of mixing conditions and organic contaminants in the runoff. Low dissolved-oxygen concentrations occurred in samples that were black in color, possibly because of organic matter. Calcium and bicarbonate were the predominant dissolved ions in samples from stormwater basins; sodium and chloride were the predominant dissolved ions in samples from the streamflow basins (see table 16 in the section entitled "Selected Water-Quality and Toxicity Data for Flow-Weighted Composite and Instantaneous Samples of Stormwater and Streamflow" at the back of the report).

Ranges in trace-metal (total recoverable) concentrations for all land uses were similar, except for heavy industrial land use. Large trace-metal concentrations for heavy industrial land use mostly are due to the large suspended-solids concentrations from 27th Avenue, which has only 15-percent impervious area. Heavy industrial land use typically has about 75-percent impervious area and probably contributes less suspended solids to stormwater runoff.

Nutrient concentrations in stormwater samples varied by two orders of magnitude. In stormwater basins, values for ammonia plus organic nitrogen (total) varied from less than 1 to $18.8 \mathrm{mg} / \mathrm{L}$. The mean was $3.54 \mathrm{mg} / \mathrm{L}$, and the median was $2.6 \mathrm{mg} / \mathrm{L}$. Total phosphorus varied from less than 0.05 to $10 \mathrm{mg} / \mathrm{L}$. The mean was $0.88 \mathrm{mg} / \mathrm{L}$, and the median was $0.53 \mathrm{mg} / \mathrm{L}$. Dissolved phosphorus varied from less than 0.05 to $2.6 \mathrm{mg} / \mathrm{L}$. The mean was $0.38 \mathrm{mg} / \mathrm{L}$, and the median was $0.28 \mathrm{mg} / \mathrm{L}$. Mean values for ammonia plus organic nitrogen (total), total phosphorus, and dissolved phosphorus were $1.04,0.30$, and $0.09 \mathrm{mg} / \mathrm{L}$, respectively. These values indicate that stormwater discharge could increase the nutrient concentrations in streamflow. 
Chemical oxygen demand (COD) for stormwater basins ranged from less than 20 to 21,000 mg/L. COD had a mean of $256 \mathrm{mg} / \mathrm{L}$ and a median of $131 \mathrm{mg} / \mathrm{L}$. COD for streamflow basins ranged from less than detection limit to $330 \mathrm{mg} / \mathrm{L}$ and had a mean of $39 \mathrm{mg} / \mathrm{L}$. These values indicate that stormwater discharge could increase COD concentrations in streamflow.

\section{Toxicity Characteristics}

Acute toxicity was measured at four stormwater stations and one streamflow station using photoluminescent marine bacterium (Photobacterium phosphoreum) to identify adverse effects of stormwater on aquatic organisms (Microbics Corporation, 1992). These bacteria emit light as a byproduct of metabolic processes that are sensitive to sample toxicity. If a sample contains harmful levels of chemical constituents, the light output of the organisms is decreased significantly. Four different concentrations of a sample of unknown toxicity were prepared, and roughly one million bacteria were exposed to each concentration. The effective concentration, expressed as a percentage of sample that reduces the light output of the bacteria by 20 percent (EC20), was determined using a spectrophotometer after sample exposures of 5 and 15 minutes.

Example:

$\begin{array}{lr}\text { Blank (0 percent stormwater) } & 100 \text { percent light output } \\ 11.25 \text { percent stormwater } & 92 \text { percent light output } \\ & \leftarrow \text { EC } 20=19.7 \text { percent stormwater } \\ 22.5 \text { percent stormwater } & 76 \text { percent light output } \\ 45 \text { percent stormwater } & 44 \text { percent light output } \\ 90 \text { percent stormwater } & 4 \text { percent light output }\end{array}$

These measurements were compared to the light output of a reagent blank not exposed to the sample. The difference in light output between the blank and the sample is attributed to the toxicity of the sample on the organisms. Acute toxicity was measured for whole- and filtered-water samples. Certain constituents have a nearly immediate toxic effect, and other constituents are toxic over longer periods of time. Some chemicals or compounds in concentrations just below toxic levels can stimulate the organisms to emit more light.

The toxicity results show that stormwater has a variable toxic effect (table 5). About 80 percent of stormwater samples had some toxic effect on aquatic organisms. Streamflow toxicity samples were collected only at Indian Bend Wash. These streamflow samples had no toxicity or stimulative effect on the bacteria. A mixture of stormwater and streamflow, however, could have a toxic effect on aquatic organisms.

\section{ESTIMATES OF CONSTITUENT LOADS}

Estimates of constituent loads for the 11 constituents designated by the USEPA that are discharged in stormwater from each municipality are part of the NPDES permit requirements. Drainage-basin characteristics and storm characteristics determined by the USGS and the FCDMC from 1991 to 1998 were used with regional regression equations (Driver and Tasker, 1990) derived from data collected during the late 1970s and early 1980s to predict constituent loads. These predictions were compared with measured loads to evaluate the accuracy of the regional regression equations. The equations then were adjusted for application to unmonitored basins in the metropolitan Phoenix area. The adjustments are regression equations that combine the regional regression equations and local data. The adjusted equations are based on a large data set that includes data from 394 local storms collected from 1991 to 1998 and 348 regional storms collected during the late 1970s and early 1980s (Driver and Tasker, 1990).

Procedures for adjusting the regional regression equations (model-adjustment procedures, MAPs) are described by Hoos and Sisolak (1993). In this report, the term prediction $\left(P_{u}\right)$ refers to a value computed from the regional regression equations that has a corresponding measured (observed) value. The term estimate refers to a value computed from a regression equation at an unmonitored drainage basin. Drainage basin, land use, and hourly precipitation data (1954-90) from Sky Harbor Airport were used with the adjusted regression equations to estimate constituent loads for each municipality in the metropolitan Phoenix area. 
Table 5. Toxicity data, Maricopa County, Arizona

[EC20, effective concentration for 20-percent reduction in biological activity; NT, nontoxic; STIM, stimulatory effect due to a combination of dissolved metals]

\begin{tabular}{|c|c|c|c|c|c|}
\hline \multirow[b]{2}{*}{ Date } & \multirow[b]{2}{*}{ Time } & \multicolumn{2}{|c|}{ EC20, raw } & \multicolumn{2}{|c|}{ EC20, filtered } \\
\hline & & 5 minutes & 15 minutes & 5 minutes & 15 minutes \\
\hline \multicolumn{6}{|c|}{09512162 Indian Bend Wash at Curry Road, Tempe, Arizona } \\
\hline $02-26-96$ & 14:00:00 & NT & NT & NT & NT \\
\hline $07-26-96$ & 8:00:00 & NT & NT & STIM & STIM \\
\hline 08-19-96 & 8:45:00 & NT & NT & NT & NT \\
\hline 09-02-96 & $12: 40: 00$ & NT & NT & NT & NT \\
\hline 01-13-97 & $14: 15: 00$ & NT & NT & NT & NT \\
\hline 02-28-97 & 8:40:00 & NT & NT & NT & NT \\
\hline 08-26-97 & 12:00:00 & NT & NT & NT & NT \\
\hline $12-22-97$ & $9: 40: 00$ & STIM & STIM & STIM & STIM \\
\hline 02-04-98 & 19:30:00 & NT & NT & STIM & STIM \\
\hline 02-09-98 & 7:40:00 & STIM & STIM & STIM & STIM \\
\hline $08-15-98$ & 23:00:00 & NT & NT & NT & NT \\
\hline $10-26-98$ & $9: 40: 00$ & STIM & STIM & STIM & STIM \\
\hline \multicolumn{6}{|c|}{09512184 48th Street Drain, Tempe, Arizona } \\
\hline $11-01-95$ & $20: 22: 00$ & 28.8 & 30.8 & 28.6 & 24.6 \\
\hline 02-01-96 & 11:38:00 & 59.8 & 61 & 72.8 & 67.3 \\
\hline $07-25-96$ & $21: 25: 00$ & 25.6 & 30.6 & 28.6 & 31.7 \\
\hline 09-02-96 & $3: 41: 00$ & 33.8 & 37.4 & 25 & 21.1 \\
\hline 11-29-96 & 6:03:00 & 68.8 & NT & 89.8 & NT \\
\hline 01-13-97 & $4: 35: 00$ & 47.8 & 54 & 53.3 & 57.1 \\
\hline 08-03-97 & $3: 27: 00$ & 26.8 & 30.2 & 24.2 & 21 \\
\hline 08-08-97 & $19: 54: 00$ & 35.9 & 33.3 & 23.7 & 25.4 \\
\hline 02-04-98 & $6: 14: 00$ & NT & NT & NT & NT \\
\hline 02-09-98 & $0: 47: 00$ & NT & 65.4 & NT & NT \\
\hline 07-06-98 & $22: 39: 00$ & 30.3 & 48.2 & 38.9 & 45 \\
\hline 07-22-98 & 10:12:00 & NT & NT & NT & NT \\
\hline \multicolumn{6}{|c|}{09512403 27th Avenue at Salt River, near Phoenix, Arizona } \\
\hline $11-01-95$ & $20: 27: 00$ & 35.7 & 34 & 34.7 & 26.2 \\
\hline $02-01-96$ & 12:09:00 & 10.6 & 4.1 & 54.5 & 42.6 \\
\hline $02-25-96$ & $23: 20: 00$ & 3.2 & 1.9 & 7.6 & 6.8 \\
\hline 03-14-96 & 8:06:00 & 31.8 & 18.4 & 32.5 & 20.6 \\
\hline 07-06-96 & $23: 22: 00$ & 6.3 & 4.2 & 13.9 & 13.8 \\
\hline 07-09-96 & 4:18:00 & 11.4 & 8.8 & 21.2 & 20.4 \\
\hline $07-25-96$ & 21:46:00 & 31.4 & 27.8 & 35.4 & 25.7 \\
\hline
\end{tabular}


Table 5. Toxicity data, Maricopa County, Arizona-Continued

\begin{tabular}{|c|c|c|c|c|c|}
\hline \multirow[b]{2}{*}{ Date } & \multirow[b]{2}{*}{ Time } & \multicolumn{2}{|c|}{ EC20, raw } & \multicolumn{2}{|c|}{ EC20, filtered } \\
\hline & & 5 minutes & 15 minutes & 5 minutes & 15 minutes \\
\hline \multicolumn{6}{|c|}{09512403 27th Avenue at Salt River, near Phoenix, Arizona-Continued } \\
\hline 01-13-97 & 5:20:00 & 34 & 30.1 & 74.6 & 69.2 \\
\hline 02-27-97 & 18:55:00 & 21.5 & 17.9 & 40.1 & 37.4 \\
\hline 08-03-97 & 7:42:00 & 27.6 & 26 & 13.5 & 12.4 \\
\hline 08-08-97 & 20:09:00 & 12.6 & 13.9 & 20.2 & 18.4 \\
\hline $12-22-97$ & 1:29:00 & 28.2 & 40.3 & 30.1 & 39.5 \\
\hline 02-04-98 & 4:59:00 & 35.3 & 49.2 & 32.3 & 33.9 \\
\hline 07-07-98 & 19:11:00 & 24.3 & 20.6 & NT & NT \\
\hline 07-22-98 & 10:36:00 & 20.7 & 17.9 & NT & NT \\
\hline \multicolumn{6}{|c|}{09513885 43rd Avenue and Peoria Avenue at Phoenix, Arizona } \\
\hline $11-01-95$ & 19:48:00 & 42.2 & 36 & 36.3 & 33.4 \\
\hline $01-31-96$ & 23:24:00 & 17.1 & 13.8 & 19.5 & 15.1 \\
\hline 07-09-96 & 3:41:00 & 21.2 & 21.3 & 37.3 & 38.8 \\
\hline 07-14-96 & $22: 18: 00$ & 24.2 & 17.4 & 28.5 & 25.6 \\
\hline 01-13-97 & 4:34:00 & 32.6 & 35.2 & 58.4 & 75.2 \\
\hline 02-27-97 & $17: 54: 00$ & 44.5 & 36.4 & 38.7 & 49.1 \\
\hline 07-19-97 & 6:20:00 & 15.3 & 14.3 & 23.5 & 23.5 \\
\hline 08-03-97 & 8:35:00 & 11.6 & 10.2 & 12.1 & 12.1 \\
\hline $12-22-97$ & 1:23:00 & 42.7 & 44.8 & NT & NT \\
\hline 02-04-98 & 6:33:00 & 78.7 & NT & 75.3 & NT \\
\hline 07-06-98 & $20: 57: 00$ & 23.2 & 29.6 & 37.3 & 39.4 \\
\hline 08-07-98 & 22:32:00 & 13.2 & 13.4 & 21 & 20.3 \\
\hline \multicolumn{6}{|c|}{09513925 67th Avenue and Olive Avenue, Glendale, Arizona } \\
\hline $11-01-95$ & 19:58:00 & 25.2 & 20 & 51 & 46.8 \\
\hline $01-31-96$ & 23:17:00 & 31.4 & 27.1 & 34.5 & 29.7 \\
\hline 07-14-96 & 22:03:00 & 49.4 & 35.2 & 66.6 & 86.2 \\
\hline $07-25-96$ & 21:13:00 & NT & NT & 80.3 & 81.5 \\
\hline 01-13-97 & 4:30:00 & 74.6 & 70.3 & NT & NT \\
\hline $02-27-97$ & 17:56:00 & 54.2 & 60.8 & NT & NT \\
\hline 08-03-97 & 5:45:00 & NT & NT & NT & NT \\
\hline 08-09-97 & 0:01:00 & 25.2 & 37 & 47.8 & 50.3 \\
\hline $12-22-97$ & 1:21:00 & NT & NT & NT & NT \\
\hline 02-04-98 & 4:38:00 & NT & NT & NT & NT \\
\hline 07-06-98 & 21:34:00 & NT & NT & 70.3 & NT \\
\hline 09-11-98 & 7:17:00 & NT & NT & NT & NT \\
\hline
\end{tabular}


The regional regression equations consist of two sets of equations that apply to regions that were delineated on the basis of mean annual precipitation (Driver and Tasker, 1990). One set of equations uses subsets of 13 explanatory variables to estimate constituent loads and volume of storm runoff (RUN) from urban drainage basins. These variables include total storm rainfall; drainage area; impervious area; land-use percentages; industrial, commercial, residential, and undeveloped; population density; total storm duration; 24-hour storm intensity with a 2-year recurrence interval; mean annual rainfall; mean nitrogen load in precipitation; and mean minimum January temperature. The regression equation variables were determined using a stepwise multipleregression analysis, and the 13-variable equations are referred to in this report as the stepwise equations. The second set of equations uses only total rainfall (TRN), drainage area (DA), and percentage of impervious area (IA) as the independent variables for estimating constituent loads.

Regressions were developed using log (base-10) transformations of the response and explanatory variables. The general form of the detransformed regional regression equation is:

$$
P_{u}=\beta_{o} \times \chi_{1}^{\beta_{1}} \times \chi_{2}^{\beta_{2}}{ }_{2}^{\beta_{n}} \times \chi_{n} \times B C F
$$

where

$$
\begin{aligned}
& P_{u}= \begin{array}{l}
\text { unadjusted storm-runoff load or volume (response variable) computed using } \\
\text { regional regression equation; }
\end{array} \\
& \beta_{o}, \beta_{1}, \beta_{2}, \beta_{n}= \begin{array}{r}
\text { regression coefficients for the adjusted regression equations; and } \\
\chi_{1}, \chi_{2}, \chi_{n}= \\
\text { explanatory variables including total storm rainfall; drainage area; impervious } \\
\text { area; land-use percentages (industrial, commercial, residential, and } \\
\text { undeveloped); total storm duration; } 24 \text {-hour storm intensity with a 2-year } \\
\text { recurrence interval; mean annual rainfall; mean nitrogen load in precipitation; } \\
\text { and mean minimum January temperature; and }
\end{array} \\
& B C F=\begin{array}{l}
\text { bias-correction factor that corrects for systematic biases that occur during the } \\
\text { detransformation of the explanatory variables. }
\end{array}
\end{aligned}
$$

The stepwise and 3-variable equations were used to predict the loads of 11 constituents and RUN for storms that were sampled by the USGS and the FCDMC. The 11 constituents were COD, suspended solids (SS), dissolved solids (DS), total nitrogen (TN), ammonia plus organic nitrogen (total; TKN), total phosphorus (TP), dissolved phosphorus (DP), total recoverable cadmium (CD), total recoverable copper (CU), total recoverable lead (PB), and total recoverable zinc $(\mathrm{ZN})$.

Observed loads were computed by multiplying the volume of runoff from a storm, in cubic feet, by the concentration of the constituent in the flow-weighted composite, in milligrams or micrograms per liter. The product then was multiplied by a conversion factor to obtain load in pounds.

\section{Adjustment of Regional Regression Equations}

The stepwise and 3-variable equations underestimated (negative bias) most observed constituent loads (table 6). In general, the 3-variable equations had a lower standard error in predicting the constituent loads than the 13-variable equations. The correlation between predicted and observed values and bias of the predictions can be used to adjust the regional regression equations for local application.

Observed, predicted, and explanatory variable values are log (base-10) transformed before correlations and regressions are computed. Explanatory variables are variable values that correlate with observed loads at a level of 10 percent; only those variables that were not used in the regional regression equations can be used in the adjustment procedure. 
Table 6. Comparison of predicted constituent loads with observed constituent loads in stormwater and comparison of predicted volume of storm runoff with observed volume of storm runoff, Maricopa County, Arizona

[Significant, probability that predicted and observed constituent loads are independent at a significance level of 0.05 ; N, no; Y, yes; minus sign (-) equations underestimate loads; plus sign (+) equations overestimate loads; NA, not applicable]

\begin{tabular}{|c|c|c|c|c|c|c|c|c|c|}
\hline \multirow[b]{2}{*}{ Variable } & \multirow[b]{2}{*}{$\begin{array}{c}\text { Number of } \\
\text { data pairs } \\
\text { used in } \\
\text { computations }\end{array}$} & \multicolumn{4}{|c|}{ Stepwise equation } & \multicolumn{4}{|c|}{ Three-variable equation } \\
\hline & & $\begin{array}{l}\text { Root mean } \\
\text { square error, } \\
\text { in percent }\end{array}$ & $\begin{array}{l}\text { Spearman } \\
\text { rank } \\
\text { correlation }\end{array}$ & Significant & Bias & $\begin{array}{l}\text { Root mean } \\
\text { square } \\
\text { error, } \\
\text { in percent }\end{array}$ & $\begin{array}{l}\text { Spearman } \\
\text { rank } \\
\text { correlation }\end{array}$ & Significant & Bias \\
\hline $\begin{array}{l}\text { Chemical oxygen } \\
\text { demand }\end{array}$ & 302 & 497 & 0.45 & $\mathrm{~N}$ & - & 195 & 0.53 & $\mathrm{~N}$ & - \\
\hline Suspended solids & 302 & 1,164 & .25 & $\mathrm{~N}$ & + & 489 & .52 & $\mathrm{~N}$ & - \\
\hline Dissolved solids & 307 & 238 & .62 & $\mathrm{~N}$ & + & 277 & .62 & $\mathrm{~N}$ & + \\
\hline Nitrogen, total & 264 & 888 & .48 & $\mathrm{~N}$ & - & 214 & .56 & $\mathrm{~N}$ & + \\
\hline $\begin{array}{l}\text { Nitrogen, ammonia plus } \\
\text { organic, total }\end{array}$ & 191 & 400 & .30 & $\mathrm{~N}$ & + & 221 & .09 & Y & - \\
\hline Phosphorus, total & 310 & 2,974 & .37 & $\mathrm{~N}$ & + & 241 & .49 & $\mathrm{~N}$ & - \\
\hline Phosphorus, dissolved & 296 & 9,859 & .30 & $\mathrm{~N}$ & - & 258 & .52 & $\mathrm{~N}$ & - \\
\hline $\begin{array}{l}\text { Cadmium, total } \\
\text { recoverable }\end{array}$ & 123 & 357 & .30 & $\mathrm{~N}$ & - & 494 & .39 & $\mathrm{~N}$ & + \\
\hline $\begin{array}{l}\text { Copper, total } \\
\text { recoverable }\end{array}$ & 224 & 3,438 & .59 & $\mathrm{~N}$ & + & 194 & .68 & $\mathrm{~N}$ & - \\
\hline Lead, total recoverable & 220 & 59,153 & .52 & $\mathrm{~N}$ & - & 4,388 & .49 & $\mathrm{~N}$ & - \\
\hline Zinc, total recoverable & 290 & 505 & .66 & $\mathrm{~N}$ & - & 205 & .52 & $\mathrm{~N}$ & - \\
\hline Storm runoff & 319 & 249 & .56 & $\mathrm{~N}$ & - & NA & NA & NA & NA \\
\hline
\end{tabular}

Correlations were computed between loads and the following explanatory variables: TRN, DA, IA, residential land use (LUR), commercial land use (LUC), industrial land use (LUI), undeveloped land use (LUN), and storm duration (DRN; table 7).

The MAP used to adjust each regional regression equation was selected according to the guidelines described by Hoos and Sisolak (1993). The guidelines are a series of conditional statements that lead to either (1) a regression (designated $R-P$ ) that uses only predicted constituent loads if predicted and observed constituent loads are correlated positively and biased or (2) a regression (designated $R-P+n V$ ) that uses predicted constituent loads and additional explanatory variables if a correlation and (or) bias do not exist, and the additional explanatory variables correlate with observed loads. This method adds additional variables to get a correlation and bias between predicted and observed loads. The $n$ in the $R-P+n V$ regression equals the number of explanatory variables used in the regression. 
Table 7. Explanatory variables that were correlated with observed constituent loads and volume of storm runoff at a level of 10 percent, Maricopa County, Arizona

[DA, drainage area; IA, impervious area; LUN, undeveloped land use; LUR, residential land use; LUI, industrial land use; DRN, total storm duration; TRN, total storm rainfall]

\begin{tabular}{|c|c|c|c|c|c|}
\hline Variable & $\begin{array}{l}\text { Explanatory } \\
\text { variables }\end{array}$ & $\begin{array}{c}\text { Number } \\
\text { of } \\
\text { samples }\end{array}$ & Variable & $\begin{array}{l}\text { Explanatory } \\
\text { variables }\end{array}$ & $\begin{array}{c}\text { Number } \\
\text { of } \\
\text { samples }\end{array}$ \\
\hline Chemical oxygen demand & $\begin{array}{l}\text { DA, IA, DRN, } \\
\text { LUN }\end{array}$ & 302 & Phosphorus, dissolved & DA, IA, LUN & 296 \\
\hline Suspended solids & TRN, DA, LUN & 302 & Cadmium, total recoverable & TRN, DA, LUN & 123 \\
\hline Dissolved solids & DA, LUN & 307 & Copper, total recoverable & TRN, DA, LUN & 224 \\
\hline Nitrogen, total & $\begin{array}{l}\text { DA, LUI, LUR, } \\
\text { DRN }\end{array}$ & 264 & Lead, total recoverable & TRN, DA, LUN & 220 \\
\hline $\begin{array}{l}\text { Nitrogen, ammonia plus } \\
\text { organic, total }\end{array}$ & $\begin{array}{l}\text { DA, LUI, LUR, } \\
\text { LUN, DRN }\end{array}$ & 191 & Zinc, total recoverable & DA, LUN, LUR & 290 \\
\hline Phosphorus, total & DA, LUN & 310 & Storm runoff & DA, LUN & 319 \\
\hline
\end{tabular}

Most equations were adjusted with the $R-P+n V$ MAP, because there was no correlation or consistent direction of bias between predicted and observed loads. The selected MAP was applied to predictions from the stepwise and 3-variable equations (table 8). The general form of the detransformed MAP equations are for the $R-P+n V$ :

$$
P_{a i}=\beta_{o}^{\prime} \times P_{u i}^{\beta_{1}^{\prime}} \times\left(\chi_{1}^{\prime}\right)^{\beta_{2}^{\prime}} \ldots\left(\chi_{n}^{\prime}\right)^{\beta_{n}^{\prime}} \times B C F^{\prime}
$$

where

$$
\begin{aligned}
P_{a i} & =\text { the adjusted storm-runoff load or volume at unmonitored station } i \\
P_{u i} & =\text { the unadjusted storm-runoff load or volume; } \\
\chi_{1}^{\prime}, \chi_{2}^{\prime}, \chi_{n}^{\prime} & =\text { explanatory variables used in the adjusted regression equations; } \\
\beta_{o}^{\prime}, \beta_{u}^{\prime}, \beta_{1}^{\prime}, \beta_{o}^{\prime}, \beta_{n}^{\prime} & =\text { regression coefficients for the adjusted regression equations; and } \\
\mathrm{BCF}^{\prime} & =\text { bias-correction factor for the adjusted regression equations. }
\end{aligned}
$$

When the MAP adjustment procedures failed, local regression equations (based solely on data collected in Maricopa County) were developed for suspended solids, dissolved solids, total phosphorus, dissolved phosphorus, total recoverable cadmium, total recoverable copper, total recoverable lead, total recoverable zinc, and storm runoff. These equations were developed using either a stepwise regression of 13 explanatory variables or a regression of 3 variables (see page 13), using log-transformed data from data collected locally.

The MAPs and local regressions greatly reduced the standard errors of the regional regression equations (compare columns 3 and 7 of table 6 with columns 3 and 5 of table 8). The selected adjusted equations for estimating constituent loads are listed in table 9, and the standard errors of the estimate are listed in table $\mathbf{1 0 .}$ 
Table 8. Calibration-error statistics for adjusting regional regression equations with local data, Maricopa County, Arizona

$[R-P+n V$, regression of observed against predicted value and explanatory variables. Local, model-adjustment procedure is inappropriate; therefore, a regression was run using only local data. >, greater than; NA, not applicable]

\begin{tabular}{lc|c||c|c}
\hline & \multicolumn{2}{c||}{ Stepwise equation } & \multicolumn{2}{c}{ Three-variable equation } \\
\cline { 2 - 3 } \multicolumn{1}{c}{ Variable } & $\begin{array}{c}\text { Model-adjustment } \\
\text { procedure }\end{array}$ & $\begin{array}{c}\text { Standard error of } \\
\text { estimate, in percent }\end{array}$ & $\begin{array}{c}\text { Model-adjustment } \\
\text { procedure }\end{array}$ & $\begin{array}{c}\text { Standard error of } \\
\text { estimate, in percent }\end{array}$ \\
\cline { 2 - 4 } Chemical oxygen demand & R-P+nV & 216 & R-P+nV & 196 \\
Suspended solids & Local & 173 & Local & 183 \\
Dissolved solids & Local & 121 & Local & 116 \\
Nitrogen, total & R-P+nV & 397 & R-P+nV & 161 \\
Nitrogen, ammonia plus organic, total & R-P+nV & 170 & R-P+nV & 174 \\
Phosphorus, total & Local & 20 & Local & 127 \\
Phosphorus, dissolved & Local & 149 & Local & 153 \\
Cadmium, total recoverable & Local & 165 & Local & $>10,000$ \\
Copper, total recoverable & Local & 133 & Local & 1,303 \\
Lead, total recoverable & Local & 15 & Local & 2,824 \\
Zinc, total recoverable & Local & 123 & Local & 129 \\
Storm runoff & Local & 124 & NA & NA \\
\hline
\end{tabular}

Table 9. Summary of regression equations selected for estimating storm-runoff constituent loads and volumes for Phoenix and surrounding municipalities

[Equation: Constant $\mathrm{x}\left(\mathrm{TRN}^{\mathrm{B} 1}\right) \mathrm{x}\left(\mathrm{DA}^{\mathrm{B} 2}\right) \ldots \mathrm{x}(\mathrm{DRN})^{\mathrm{B} 9}$. Constituent values are in pounds, and storm runoff is in cubic feet. Dashes indicate variable is not used in equation]

\begin{tabular}{|c|c|c|c|c|c|c|c|c|c|c|}
\hline \multirow[b]{2}{*}{ Variable } & \multirow[b]{2}{*}{ Constant } & \multirow[b]{2}{*}{$\begin{array}{l}\text { Total storm } \\
\text { rainfall, } \\
\text { in inches } \\
\text { (TRN) }\end{array}$} & \multirow[b]{2}{*}{$\begin{array}{c}\text { Drainage } \\
\text { area, in } \\
\text { square } \\
\text { miles (DA) }\end{array}$} & \multirow{2}{*}{$\begin{array}{l}\text { Imper- } \\
\text { vious } \\
\text { area1, in } \\
\text { percent } \\
\text { (IA) }\end{array}$} & \multicolumn{4}{|c|}{ Land use, in percent } & \multirow{2}{*}{$\begin{array}{c}\text { Mean } \\
\text { annual } \\
\text { nitrogen } \\
\text { load, in } \\
\text { pounds } \\
\text { (MNL) }\end{array}$} & \multirow{2}{*}{$\begin{array}{c}\text { Storm } \\
\text { duration } \\
\text { in } \\
\text { minutes } \\
\text { (DRN) }\end{array}$} \\
\hline & & & & & $\begin{array}{l}\text { Industrial1 } \\
\text { (LUI) }\end{array}$ & $\begin{array}{c}\text { Resi- } \\
\text { dential'1 }^{1} \\
\text { (LUR) }\end{array}$ & $\begin{array}{c}\text { Com- } \\
\text { mercial' } \\
\text { (LUC) }\end{array}$ & $\begin{array}{c}\text { Undevel- } \\
\text { oped }^{1} \\
\text { (LUN) }\end{array}$ & & \\
\hline $\begin{array}{l}\text { Chemical oxygen } \\
\text { demand }\end{array}$ & 636 & 0.573 & 0.650 & 0.347 & --- & --- & --- & --- & --- & 0.077 \\
\hline Suspended solids & 1,780 & .499 & .719 & -.074 & --- & --- & --- & --- & --- & --- \\
\hline Dissolved solids & 200 & -.160 & .792 & .359 & --- & --- & --- & --- & --- & --- \\
\hline Nitrogen, total & 19.2 & .512 & .664 & .297 & --- & --- & --- & --- & --- & -.214 \\
\hline $\begin{array}{l}\text { Nitrogen, ammonia } \\
\text { plus organic, total }\end{array}$ & 20.8 & .182 & .225 & --- & 0.102 & -0.027 & 0.070 & -0.059 & 0.366 & -.166 \\
\hline Phosphorus, total & 4.99 & .034 & .747 & -.018 & --- & --- & --- & --- & --- & --- \\
\hline $\begin{array}{r}\text { Phosphorus, } \\
\text { dissolved }\end{array}$ & 1.58 & .106 & .049 & .116 & --- & --- & --- & --- & --- & --- \\
\hline $\begin{array}{l}\text { Cadmium, total } \\
\text { recoverable }\end{array}$ & .030 & .754 & .738 & --- & --- & -.172 & --- & --- & --- & -.188 \\
\hline $\begin{array}{l}\text { Copper, total } \\
\text { recoverable }\end{array}$ & 1.60 & .495 & .978 & --- & --- & -.245 & --- & --- & --- & -.256 \\
\hline $\begin{array}{l}\text { Lead, total } \\
\quad \text { recoverable }\end{array}$ & .394 & .573 & .891 & --- & .324 & --- & .286 & -.540 & --- & -.254 \\
\hline $\begin{array}{l}\text { Zinc, total } \\
\text { recoverable }\end{array}$ & 6.61 & .456 & .879 & --- & --- & -.231 & .156 & -.170 & --- & -.250 \\
\hline Storm runoff & 224,000 & .170 & .862 & --- & .027 & --- & .214 & -.419 & --- & --- \\
\hline
\end{tabular}


Table 10. Summary statistics of regression equations for estimating storm-runoff constituent loads and volumes for Phoenix and surrounding municipalities

$[R-P+n V$, regression of observed against predicted value and explanatory variables]

\begin{tabular}{lccc}
\hline \multicolumn{1}{c}{ Variable } & $\begin{array}{c}\text { Number of } \\
\text { samples }\end{array}$ & $\begin{array}{c}\text { Standard error of } \\
\text { estimate, in percent }\end{array}$ & Method \\
\hline Chemical oxygen demand & 302 & 196 & R-P+nV 3-variable \\
Suspended solids & 302 & 183 & Local 3-variable \\
Dissolved solids & 307 & 116 & Local 3-variable \\
Nitrogen, total & 264 & 161 & R-P+nV 3-variable \\
Nitrogen, ammonia plus organic, total & 191 & 170 & R-P+nV 13-variable \\
Phosphorus, total & 310 & 127 & Local 3-variable \\
Phosphorus, dissolved & 296 & 153 & Local 3-variable \\
Cadmium, total recoverable & 123 & 165 & Local 13-variable \\
Copper, total recoverable & 224 & 133 & Local 13-variable \\
Lead, total recoverable & 220 & 15 & Local 13-variable \\
Zinc, total recoverable & 290 & 123 & Local 13-variable \\
Storm runoff & 319 & 124 & Local 13-variable \\
\hline
\end{tabular}

In the cases of suspended solids, total phosphorus, and dissolved phosphorus, the local three-variable regression was chosen even though the stepwise regressions had a lower standard error of the estimate. The three-variable regression was chosen because it removed the variability of land use, which is a component in the stepwise regressions. The variability of land-use characteristics caused a problem with the estimates of loads, the relation of suspended solids and dissolved solids, and the relation of total phosphorus and dissolved phosphorus. An assumption was made from the observed loads that suspended-solids loads should be larger than dissolvedsolids loads, and total-phosphorus loads should be larger than dissolved-phosphorus loads. Local three-variable regressions were used to make this relation true.

\section{Load Estimates for Phoenix and Surrounding Municipalities}

The equations shown in table 9, land-use data, and municipality and drainage-basin boundaries were used to estimate constituent loads for each municipality. Land-use and boundary data were obtained from the FCDMC and stored in a GIS. Each municipality and major drainage basin was subdivided into sections of 640 acres or less, and equations were applied to each section. This area was selected because 640 acres is about the mean area of drainage basins used in the adjustment procedures.

Each land-use type was assumed to be represented by a specific percentage of impervious area (Flood Control District of Maricopa County, 1993). The amount of each land use and impervious area in each of the sections was quantified using a GIS. Noncontributing areas, such as lakes and canals, areas with agricultural land use, and areas 
within a municipality but not part of the municipality were excluded from all computations when possible.

The metropolitan Phoenix area, however, has many dry wells and retention basins, and data on their locations and contributing areas are not available. Constituent loads presented in this report, therefore, could be overestimated.

Runoff from summer monsoons and winter cold fronts contributes to the annual constituent loads in Phoenix and the surrounding areas. Both types of storms have a mean TRN of 0.46 in., but summer and winter storms have different mean DRNs, 5.06 and 14.1 hours, respectively. Either type of storm can occur during spring (April through June); storms during this period have a mean storm TRN of $0.36 \mathrm{in}$. and a mean DRN of 8.56 hours. Mean TRN and DRN values were calculated by using log (base 10) transformed rainfall data from Sky Harbor International Airport from 1954 to 1990 and by specifying the number of hours without rainfall to differentiate storms (table 2). Varying the time between storms by 50 percent had little effect on the mean TRN and storm frequency. The mean annual rainfall is 7.66 in. (National Oceanic and Atmospheric Administration, 1998; table 1, this report).

Mean seasonal loads for suspended solids, dissolved solids, total nitrogen, ammonia plus organic nitrogen (total), total phosphorus, and dissolved phosphorus are the same for summer and winter (tables 11 and 12) because they have the same mean TRN. Mean seasonal loads for spring storms were estimated using the mean TRN value of 0.36 in. (table 13). Mean annual constituent loads were estimated by summing mean seasonal constituent loads (table 14).

Table 11. Estimated mean summer constituent loads for Phoenix and surrounding municipalities

[Units for all estimates are pounds]

\begin{tabular}{|c|c|c|c|c|c|c|c|c|c|c|c|}
\hline City & $\begin{array}{l}\text { Chemical } \\
\text { oxygen } \\
\text { demand }\end{array}$ & $\begin{array}{l}\text { Suspended } \\
\text { solids }\end{array}$ & $\begin{array}{l}\text { Dissolved } \\
\text { solids }\end{array}$ & $\begin{array}{c}\text { Total } \\
\text { nitrogen }\end{array}$ & $\begin{array}{l}\text { Ammonia } \\
\text { plus } \\
\text { organic } \\
\text { nitrogen } \\
\text { (total) }\end{array}$ & $\begin{array}{c}\text { Total } \\
\text { phosphorus }\end{array}$ & $\begin{array}{l}\text { Dissolved } \\
\text { phosphorus }\end{array}$ & $\begin{array}{l}\text { Total } \\
\text { recover- } \\
\text { able } \\
\text { cadmium }\end{array}$ & $\begin{array}{l}\text { Total } \\
\text { recover- } \\
\text { able } \\
\text { copper }\end{array}$ & $\begin{array}{c}\text { Total } \\
\text { recover- } \\
\text { able lead }\end{array}$ & $\begin{array}{c}\text { Total } \\
\text { recover- } \\
\text { able zinc }\end{array}$ \\
\hline Chandler & 311,000 & 483,000 & 270,000 & 3,920 & 3,040 & 2,200 & 1,090 & 1.79 & 65.2 & 9.44 & 180 \\
\hline Gilbert & 214,000 & 436,000 & 186,000 & 2,770 & 2,320 & 1,910 & 875 & 1.67 & 64.2 & 5.07 & 157 \\
\hline Glendale & 405,000 & 691,000 & 352,000 & 5,120 & 4,290 & 3,090 & 1,550 & 2.78 & 106 & 15.1 & 287 \\
\hline Guadalupe & 5,710 & 6,600 & 4,520 & 69.7 & 73.6 & 30.9 & 27.7 & .019 & .512 & .226 & 2.12 \\
\hline Mesa & 689,000 & 976,000 & 603,000 & 8,570 & 6,510 & 4,500 & 2,390 & 3.53 & 125 & 28.0 & 386 \\
\hline \multicolumn{12}{|l|}{ Paradise } \\
\hline Valley & 51,200 & 130,000 & 42,600 & 680 & 769 & 553 & 286 & .608 & 24.0 & .940 & 61.5 \\
\hline Peoria & 341,000 & 938,000 & 290,000 & 4,540 & 4,870 & 3,930 & 1,730 & 4.11 & 166 & 7.70 & 366 \\
\hline Phoenix & $2,230,000$ & $3,590,000$ & $1,950,000$ & 28,000 & 22,000 & 16,200 & 7,800 & 13.6 & 507 & 104 & 1,490 \\
\hline Scottsdale & 706,000 & $1,480,000$ & 607,000 & 9,120 & 7,740 & 6,410 & 2,940 & 5.63 & 214 & 20.6 & 529 \\
\hline Tempe & 267,000 & 276,000 & 233,000 & 3,220 & 2,530 & 1,340 & 826 & .957 & 32.0 & 20.2 & 138 \\
\hline Tolleson & 30,600 & 42,900 & 26,400 & 384 & 356 & 200 & 118 & .193 & 7.29 & .913 & 18.5 \\
\hline Youngtown & 7,720 & 8,870 & 5,990 & 94.0 & 92.1 & 41.3 & 41.2 & .026 & .666 & .241 & 2.96 \\
\hline
\end{tabular}


Table 12. Estimated mean winter constituent loads for Phoenix and surrounding municipalities

[Units for all estimates are pounds]

\begin{tabular}{|c|c|c|c|c|c|c|c|c|c|c|c|}
\hline City & $\begin{array}{c}\text { Chemical } \\
\text { oxygen } \\
\text { demand }\end{array}$ & $\begin{array}{l}\text { Suspended } \\
\text { solids }\end{array}$ & $\begin{array}{l}\text { Dissolved } \\
\text { solids }\end{array}$ & $\begin{array}{c}\text { Total } \\
\text { nitrogen }\end{array}$ & $\begin{array}{c}\text { Ammonia } \\
\text { plus } \\
\text { organic } \\
\text { nitrogen } \\
\text { (total) }\end{array}$ & $\begin{array}{c}\text { Total } \\
\text { phosphorus }\end{array}$ & $\begin{array}{c}\text { Dissolved } \\
\text { phosphorus }\end{array}$ & $\begin{array}{c}\text { Total } \\
\text { recover- } \\
\text { able } \\
\text { cadmium }\end{array}$ & $\begin{array}{l}\text { Total } \\
\text { recover- } \\
\text { able } \\
\text { copper }\end{array}$ & $\begin{array}{c}\text { Total } \\
\text { recover- } \\
\text { able lead }\end{array}$ & $\begin{array}{c}\text { Total } \\
\text { recover- } \\
\text { able zinc }\end{array}$ \\
\hline Chandler & 288,000 & 483,000 & 270,000 & 3,140 & 2,560 & 2,200 & 1,090 & 1.48 & 50.2 & 7.28 & 139 \\
\hline Gilbert & 198,000 & 436,000 & 186,000 & 2,230 & 1,960 & 1,910 & 875 & 1.38 & 49.4 & 3.91 & 122 \\
\hline Glendale & 374,000 & 691,000 & 352,000 & 4,110 & 3,620 & 3,090 & 1,550 & 2.29 & 81.8 & 11.6 & 222 \\
\hline Guadalupe & 5,280 & 6,600 & 4,520 & 56.0 & 62.1 & 30.9 & 27.7 & .016 & .394 & .174 & 1.64 \\
\hline Mesa & 637,000 & 976,000 & 603,000 & 6,890 & 5,500 & 4,500 & 2,390 & 2.91 & 96.5 & 21.6 & 299 \\
\hline \multicolumn{12}{|l|}{ Paradise } \\
\hline Valley & 47,300 & 130,000 & 42,600 & 546 & 649 & 553 & 286 & .501 & 18.5 & .725 & 47.6 \\
\hline Peoria & 315,000 & 938,000 & 290,000 & 3,650 & 4,110 & 3,930 & 1,730 & 3.39 & 128 & 5.94 & 283 \\
\hline Phoenix & $2,060,000$ & $3,590,000$ & $1,950,000$ & 22,500 & 18,500 & 16,200 & 7,800 & 11.2 & 390 & 80.0 & 1,160 \\
\hline Scottsdale & 653,000 & $1,480,000$ & 607,000 & 7,330 & 6,530 & 6,410 & 2,940 & 4.64 & 165 & 15.9 & 409 \\
\hline Tempe & 247,000 & 276,000 & 233,000 & 2,590 & 2,130 & 1,340 & 826 & .790 & 24.6 & 15.6 & 107 \\
\hline Tolleson & 28,300 & 42,900 & 26,400 & 308 & 300 & 200 & 118 & .160 & 5.61 & .704 & 14.3 \\
\hline Youngtown & 7,140 & 8,870 & 5,990 & 75.5 & 77.7 & 41.3 & 41.2 & .021 & .513 & .185 & 2.29 \\
\hline
\end{tabular}

Table 13. Estimated mean spring constituent loads for Phoenix and surrounding municipalities

[Units for all estimates are pounds]

\begin{tabular}{|c|c|c|c|c|c|c|c|c|c|c|c|}
\hline City & $\begin{array}{c}\text { Chemical } \\
\text { oxygen } \\
\text { demand }\end{array}$ & $\begin{array}{l}\text { Suspended } \\
\text { solids }\end{array}$ & $\begin{array}{l}\text { Dissolved } \\
\text { solids }\end{array}$ & $\begin{array}{c}\text { Total } \\
\text { nitrogen }\end{array}$ & $\begin{array}{c}\text { Ammonia } \\
\text { plus } \\
\text { organic } \\
\text { nitrogen } \\
\text { (total) }\end{array}$ & $\begin{array}{c}\text { Total } \\
\text { phosphorus }\end{array}$ & $\begin{array}{l}\text { Dissolved } \\
\text { phosphorus }\end{array}$ & $\begin{array}{c}\text { Total } \\
\text { recover- } \\
\text { able } \\
\text { cadmium }\end{array}$ & $\begin{array}{l}\text { Total } \\
\text { recover- } \\
\text { able } \\
\text { copper }\end{array}$ & $\begin{array}{c}\text { Total } \\
\text { recover- } \\
\text { able lead }\end{array}$ & $\begin{array}{c}\text { Total } \\
\text { recover- } \\
\text { able zinc }\end{array}$ \\
\hline Chandler & 74,200 & 122,000 & 80,200 & 882 & 761 & 624 & 304 & 0.385 & 14.4 & 2.05 & 40.3 \\
\hline Gilbert & 51,100 & 110,000 & 55,400 & 624 & 581 & 542 & 243 & .360 & 14.2 & 1.10 & 35.2 \\
\hline Glendale & 96,500 & 175,000 & 105,000 & 1,150 & 1,070 & 875 & 433 & .598 & 23.5 & 3.28 & 64.3 \\
\hline Guadalupe & 1,360 & 1,670 & 1,340 & 15.7 & 18.4 & 8.76 & 7.71 & .004 & .113 & .049 & .474 \\
\hline Mesa & 164,000 & 247,000 & 179,000 & 1,930 & 1,630 & 1,280 & 666 & .759 & 27.7 & 6.09 & 86.4 \\
\hline \multicolumn{12}{|l|}{ Paradise } \\
\hline Valley & 12,200 & 33,000 & 12,600 & 153 & 192 & 157 & 79.5 & .131 & 5.32 & .204 & 13.8 \\
\hline Peoria & 81,200 & 237,000 & 86,000 & 1,020 & 1,220 & 1,110 & 482 & .884 & 36.7 & 1.67 & 82.0 \\
\hline Phoenix & 531,000 & 907,000 & 579,000 & 6,300 & 5,500 & 4,580 & 2,170 & 2.93 & 112 & 22.5 & 335 \\
\hline Scottsdale & 168,000 & 373,000 & 181,000 & 2,060 & 1,940 & 1,820 & 818 & 1.21 & 47.4 & 4.47 & 118 \\
\hline Tempe & 63,600 & 69,600 & 69,100 & 726 & 633 & 379 & 230 & .206 & 7.08 & 4.39 & 30.9 \\
\hline Tolleson & 7,310 & 10,900 & 7,850 & 86 & 89 & 56.6 & 32.9 & .042 & 1.61 & .198 & 4.14 \\
\hline Youngtown & 1,840 & 2,240 & 1,780 & 21.2 & 23.1 & 11.7 & 11.5 & .006 & .147 & .052 & .664 \\
\hline
\end{tabular}


Table 14. Estimated mean annual constituent loads for Phoenix and surrounding municipalities

[Units for all estimates are pounds]

\begin{tabular}{|c|c|c|c|c|c|c|c|c|c|c|c|}
\hline City & $\begin{array}{l}\text { Chemical } \\
\text { oxygen } \\
\text { demand }\end{array}$ & $\begin{array}{l}\text { Suspended } \\
\text { solids }\end{array}$ & $\begin{array}{l}\text { Dissolved } \\
\text { solids }\end{array}$ & $\begin{array}{c}\text { Total } \\
\text { nitrogen }\end{array}$ & $\begin{array}{l}\text { Ammonia } \\
\text { plus } \\
\text { organic } \\
\text { nitrogen } \\
\text { (total) }\end{array}$ & $\begin{array}{c}\text { Total } \\
\text { phosphorus }\end{array}$ & $\begin{array}{l}\text { Dissolved } \\
\text { phosphorus }\end{array}$ & $\begin{array}{c}\text { Total } \\
\text { recover- } \\
\text { able } \\
\text { cadmium }\end{array}$ & $\begin{array}{c}\text { Total } \\
\text { recover- } \\
\text { able } \\
\text { copper }\end{array}$ & $\begin{array}{c}\text { Total } \\
\text { recover- } \\
\text { able lead }\end{array}$ & $\begin{array}{c}\text { Total } \\
\text { recover- } \\
\text { able zinc }\end{array}$ \\
\hline Chandler & 673,000 & $1,090,000$ & 620,000 & 7,940 & 6,360 & 5,020 & 2,480 & 3.66 & 130 & 18.8 & 359 \\
\hline Gilbert & 463,000 & 982,000 & 427,000 & 5,620 & 4,860 & 4,360 & 1,990 & 3.41 & 128 & 10.1 & 314 \\
\hline Glendale & 876,000 & $1,560,000$ & 809,000 & 10,400 & 8,980 & 7,060 & 3,530 & 5.67 & 211 & 30.0 & 573 \\
\hline Guadalupe & 12,400 & 14,900 & 10,400 & 141 & 154 & 70.6 & 63.1 & .039 & 1.02 & .449 & 4.23 \\
\hline Mesa & $1,490,000$ & $2,200,000$ & $1,380,000$ & 17,400 & 13,600 & 10,300 & 5,450 & 7.20 & 249 & 55.7 & 771 \\
\hline $\begin{array}{l}\text { Paradise } \\
\text { Valley }\end{array}$ & 111,000 & 293,000 & 97,800 & 1,380 & 1,610 & 1,260 & 652 & 1.24 & 47.8 & 1.87 & 123 \\
\hline Peoria & 737,000 & $2,110,000$ & 666,000 & 9,210 & 10,200 & 8,970 & 3,940 & 8.38 & 331 & 15.3 & 731 \\
\hline Phoenix & $4,820,000$ & $8,090,000$ & $4,480,000$ & 56,800 & 46,000 & 37,000 & 17,800 & 27.7 & 1,010 & 206 & 2,980 \\
\hline Scottsdale & $1,530,000$ & $3,330,000$ & $1,400,000$ & 18,500 & 16,200 & 14,600 & 6,700 & 11.5 & 426 & 41.0 & 1,060 \\
\hline Tempe & 578,000 & 622,000 & 535,000 & 6,540 & 5,290 & 3,060 & 1,880 & 1.95 & 63.7 & 40.2 & 276 \\
\hline Tolleson & 66,200 & 96,700 & 60,600 & 778 & 745 & 457 & 269 & .395 & 14.5 & 1.82 & 36.9 \\
\hline Youngtown & 16,700 & 20,000 & 13,800 & 191 & 193 & 94.3 & 93.9 & .053 & 1.33 & .478 & 5.91 \\
\hline
\end{tabular}

Mean seasonal and mean annual volumes of runoff also were estimated (table 15). Estimates were made by assuming that rainfall at Sky Harbor International Airport represents the entire Maricopa County area. On the basis of rainfall records, the eastern part of the metropolitan Phoenix area, however, received more rainfall than other areas during this study. Orographic effects of the surrounding mountains could be a significant factor influencing the areal distribution of storm characteristics, mean annual rainfall, and constituent loads. Total storm rainfall can vary 1 in. or more from one side of the metropolitan Phoenix area to the other. 
Table 15. Estimated mean seasonal and annual volumes of runoff for Phoenix and surrounding municipalities

\begin{tabular}{|c|c|c|c|}
\hline City & Runoff, in cubic feet & City & Runoff, in cubic feet \\
\hline \multicolumn{4}{|c|}{ Summer storms } \\
\hline Chandler & $27,700,000$ & Peoria & $29,900,000$ \\
\hline Gilbert & $18,500,000$ & Phoenix & $262,000,000$ \\
\hline Glendale & $41,300,000$ & Scottsdale & $69,500,000$ \\
\hline Guadalupe & 523,000 & Tempe & $35,200,000$ \\
\hline Mesa & $72,300,000$ & Tolleson & $1,940,000$ \\
\hline Paradise Valley & $4,410,000$ & Youngtown & 841,000 \\
\hline \multicolumn{4}{|c|}{ Winter storms } \\
\hline Chandler & $27,700,000$ & Peoria & $29,900,000$ \\
\hline Gilbert & $18,500,000$ & Phoenix & $262,000,000$ \\
\hline Glendale & $41,300,000$ & Scottsdale & $69,500,000$ \\
\hline Guadalupe & 523,000 & Tempe & $35,200,000$ \\
\hline Mesa & $72,300,000$ & Tolleson & $1,940,000$ \\
\hline Paradise Valley & $4,410,000$ & Youngtown & 841,000 \\
\hline \multicolumn{4}{|c|}{ Spring storms } \\
\hline Chandler & $7,590,000$ & Peoria & $8,180,000$ \\
\hline Gilbert & $5,080,000$ & Phoenix & $71,700,000$ \\
\hline Glendale & $11,300,000$ & Scottsdale & $19,000,000$ \\
\hline Guadalupe & 143,000 & Tempe & $8,540,000$ \\
\hline Mesa & $19,800,000$ & Tolleson & 532,000 \\
\hline Paradise Valley & $1,210,000$ & Youngtown & 231,000 \\
\hline \multicolumn{4}{|c|}{ Annual totals } \\
\hline Chandler & $63,000,000$ & Peoria & $68,000,000$ \\
\hline Gilbert & $42,100,000$ & Phoenix & $596,000,000$ \\
\hline Glendale & 93,900,000 & Scottsdale & $158,000,000$ \\
\hline Guadalupe & $1,060,000$ & Tempe & $80,000,000$ \\
\hline Mesa & $1,190,000$ & Tolleson & $4,410,000$ \\
\hline Paradise Valley & $10,000,000$ & Youngtown & $1,910,000$ \\
\hline
\end{tabular}




\section{SUMMARY}

From October 1991 to October 1998, stormwater was sampled in the metropolitan Phoenix area from six drainage basins with residential, light industrial, heavy industrial, commercial, and undeveloped land uses. Streamflow was sampled from the Salt River at Priest Drive, near Phoenix (09512165) and Indian Bend Wash at Curry Road, at Tempe (09512162). Stormwater also was sampled at nine drainage basins with residential, industrial, commercial, and mixed land use during 1991-98 by the FCDMC. Initial runoff from several sites typically was black in color. Specific-conductance values commonly decreased during storms; the decreasing values indicated that most soluble constituents were washed from exposed surfaces in the initial runoff or that constituent concentrations were diluted. Event-mean concentrations of constituents measured in stormwater commonly varied by an order of magnitude. Instantaneous concentrations of most constituents measured in streamflow from the Salt River and Indian Bend Wash were within the range of concentrations measured in stormwater from urban drainage basins. Event-mean concentrations of chemical oxygen demand, total suspended solids, and most nutrients were greater in urban stormwater than in streamflow.

Mean seasonal and mean annual loads of 11 constituents and volumes of runoff were estimated for municipalities in the study area. Constituent loads were estimated by using data collected in the study area to adjust regional regression equations for local application. The equations requiring the $R-P+n V$ adjustment procedure to estimate constituent loads for COD, total nitrogen, and ammonia plus organic nitrogen (total) had standard errors that ranged from 161 to 296 percent. The large standard errors of the prediction are due to the large variability of the constituent concentration data used in the regression analysis. The MAP procedures could not be used to adjust the regression equations for suspended solids, dissolved solids, total phosphorus, dissolved phosphorus, total recoverable cadmium, total recoverable copper, total recoverable lead, total recoverable zinc, and storm runoff because there were no correlations with additional explanatory variables. Local regressions were developed for these constituents using only data collected locally. Land-use data, rainfall data, and a GIS were used with the adjusted equations to estimate constituent loads and volume of runoff from each municipality.

\section{SELECTED REFERENCES}

Driver, N.E., and Tasker, G.D., 1990, Techniques for estimation of storm-runoff loads, volumes, and selected constituent concentrations in urban watersheds in the United States: U.S. Geological Survey Water-Supply Paper 2363,44 p.

Flood Control District of Maricopa County, 1993, Gilbert-Chandler area drainage master study-Volume 1, Current conditions hydrology, Final report, July 1993: Phoenix, Arizona, Flood Control District of Maricopa County report, v.p.

Fossum, K.D., and Davis, R.G., 1996, Physical, chemical, biological, and toxicity data from the study of urban stormwater and ephemeral streams, Maricopa County, Arizona, water years 1992-95: U.S. Geological Survey Open-File Report 96-394, $71 \mathrm{p}$.

Hem, J.D., 1985, Study and interpretation of the chemical characteristics of natural water, 3rd ed.: U.S. Geological Survey Water-Supply Paper 2254, 263 p.

Hoos, A.B., and Sisolak, J.K., 1993, Procedures for adjusting regional regression models of urban-runoff quality using local data: U.S. Geological Survey Open-File Report 93-39, 39 p.

Kennedy, E.J., 1984, Discharge ratings at gaging stations: U.S. Geological Survey Techniques of Water-Resources Investigations, book 3, chap. A10, 59 p.

Lopes, T.J., Fossum, K.D., Phillips, J.V., and Monical, J.E., 1995, Statistical summary of selected physical, chemical, and microbial characteristics, and estimates of constituent loads in urban stormwater, Maricopa County, Arizona: U.S. Geological Survey Water-Resources Investigations Report 94-4240, 62 p.

Maricopa Association of Governments, 1998, 1998 MAG regional development summary-A report on population, employment, housing, and commerce in Maricopa County: Phoenix, Arizona, Maricopa Association of Governments report, $58 \mathrm{p}$.

Microbics Corporation, 1992, Microtox manual, a toxicity testing handbook, Volumes I-IV: Carlsbad, California, Microbics Corporation, $476 \mathrm{p}$. 
National Oceanic and Atmospheric Administration, 1998, Local climatological data-Annual summary with comparative data, Phoenix, Arizona: U.S. Department of Commerce, National Oceanic and Atmospheric Administration report, 8 p. Rantz, S.E., and others, 1982, Measurement and computation of streamflow-Volume 1, Measurement of stage and discharge: U.S. Geological Survey Water-Supply Paper 2175, 284 p.

Sabol, G.V., Rumann, J.M., Khalili, D., and Waters, S.D., 1990, Hydrologic design manual for Maricopa County, Arizona: Phoenix, Arizona, Flood Control District of Maricopa County report, v.p.

Smith, C.F., Rigas, P.D., Ham, L.K., Duet, N.R., and Anning, D.W., 1994, Water resources data, Arizona water year 1993 : U.S. Geological Survey Water-Data Report AZ-93-1, 360 p. 
Table 16. Summary data

[ft, feet; $\mathrm{ft} 3 / \mathrm{s}$, cubic feet per second; MGD, million gallons per day; in., inches; min, minute; ${ }^{\circ} \mathrm{C}$, degrees Celsius; $\mu \mathrm{S} / \mathrm{cm}$ at $25^{\circ} \mathrm{C}$, microsiemens per centimeter at $25^{\circ} \mathrm{C}$; NA, not analyzed; E, estimated; mm of $\mathrm{HG}$, millimeters of mercury; $\mathrm{mg} / \mathrm{L}$, milligrams per liter; <, less than; >, greater than; $\mu \mathrm{g} / \mathrm{L}$, micrograms per liter]

\begin{tabular}{|c|c|c|c|c|c|c|c|c|c|c|c|c|}
\hline $\begin{array}{c}\text { Station } \\
\text { identifi- } \\
\text { cation } \\
\text { number }\end{array}$ & Date & Time & $\begin{array}{c}\text { Gage } \\
\text { height } \\
\text { (ft) }\end{array}$ & $\begin{array}{c}\text { Dis- } \\
\text { charge } \\
\left(\mathrm{ft}^{3} / \mathrm{s}\right)\end{array}$ & $\begin{array}{l}\text { Storm- } \\
\text { water } \\
\text { flow } \\
\text { (MGD) }\end{array}$ & $\begin{array}{l}\text { Precipi- } \\
\text { tation, } \\
\text { total } \\
\text { (in./storm) }\end{array}$ & $\begin{array}{c}\text { 5-minute } \\
\text { maximum } \\
\text { precipi- } \\
\text { tation } \\
\text { intensity } \\
\text { (in./5 min) }\end{array}$ & $\begin{array}{c}\text { Total } \\
\text { storm } \\
\text { duration } \\
\text { (hours) }\end{array}$ & $\begin{array}{c}\text { Antece- } \\
\text { dent dry } \\
\text { days }\end{array}$ & $\begin{array}{l}\text { Specific } \\
\text { conduct- } \\
\text { ance } \\
(\mu \mathrm{S} / \mathrm{cm} \text { at } \\
\left.25^{\circ} \mathrm{C}\right)\end{array}$ & $\begin{array}{c}\text { Specific } \\
\text { conduct- } \\
\text { ance, } \\
\text { laboratory } \\
(\mu \mathrm{S} / \mathrm{cm} \text { at } \\
\left.25^{\circ} \mathrm{C}\right)\end{array}$ & $\begin{array}{c}\text { pH, whole } \\
\text { water, field } \\
\text { (standard } \\
\text { units) }\end{array}$ \\
\hline 09512162 & 02-26-96 & 1400 & 0.86 & 2.5 & NA & NA & NA & NA & NA & 1,050 & 1,110 & 8.3 \\
\hline 09512162 & 07-26-96 & 0800 & .88 & 2.5 & NA & NA & NA & NA & NA & 1,160 & 1,170 & 7.3 \\
\hline 09512162 & 08-19-96 & 0845 & 1.03 & 18 & NA & NA & NA & NA & NA & 1,010 & 1,030 & 8 \\
\hline 09512162 & 09-02-96 & 1240 & 1.41 & 138 & NA & NA & NA & NA & NA & 684 & 954 & 6.7 \\
\hline 09512162 & 01-13-97 & 1415 & 1.04 & 30 & NA & NA & NA & NA & NA & 372 & 348 & 7.8 \\
\hline 09512162 & 02-28-97 & 0840 & 1.01 & 10 & NA & NA & NA & NA & NA & 658 & 699 & 7.9 \\
\hline 09512162 & 08-26-97 & 1200 & NA & E10 & NA & NA & NA & $\mathrm{NA}$ & NA & 151 & 157 & 8.5 \\
\hline 09512162 & $12-22-97$ & 0940 & 1.02 & 15 & NA & NA & NA & NA & NA & 793 & 836 & 8.2 \\
\hline 09512162 & 02-04-98 & 1930 & 1.54 & 215 & NA & NA & NA & NA & NA & 755 & 794 & 7.4 \\
\hline 09512162 & 02-09-98 & 0740 & 1.16 & 48 & NA & NA & NA & NA & NA & 320 & 355 & 7.5 \\
\hline 09512165 & 04-01-98 & 1130 & 3.58 & 1,800 & NA & NA & NA & NA & NA & 418 & 447 & 7.8 \\
\hline 09512184 & $11-01-95$ & 2022 & .63 & 22 & .16 & .92 & .25 & 2.3 & 34 & 43 & 264 & 7.3 \\
\hline 09512184 & 02-01-96 & 1138 & .24 & 3.3 & .08 & .43 & .11 & 14.6 & 8 & 130 & 192 & 7.1 \\
\hline 09512184 & $07-25-96$ & 2125 & .33 & 6 & .07 & .33 & .05 & 1.3 & 10 & 326 & 596 & 6.9 \\
\hline 09512184 & 09-02-96 & 0341 & .29 & 4.7 & .07 & .24 & .1 & .93 & 3 & 254 & 290 & 6.8 \\
\hline 09512184 & 11-29-96 & 0603 & .21 & 2.3 & .05 & .21 & .09 & 1.2 & 7 & 207 & 224 & 8 \\
\hline 09512184 & 01-13-97 & 0435 & .31 & 5.3 & .09 & .41 & .05 & 1.2 & 44 & 136 & 231 & 8.3 \\
\hline 09512184 & 08-03-97 & 0327 & .24 & 3.3 & .03 & .25 & .2 & .63 & 3 & 535 & 523 & 7.1 \\
\hline 09512184 & 08-08-97 & 1954 & .33 & 6.1 & .1 & .55 & .18 & .8 & 5 & 279 & 244 & 7.1 \\
\hline 09512184 & 02-04-98 & 0614 & .2 & 2.3 & .12 & .78 & .04 & 5.4 & 25 & 69 & 97 & 7 \\
\hline 09512184 & 02-09-98 & 0047 & .23 & 3 & .13 & .83 & .03 & 14.9 & 4 & 47 & 76 & 7.7 \\
\hline 09512403 & $11-01-95$ & 2027 & .59 & 8.1 & .24 & .46 & .07 & 2.2 & 53 & 144 & 235 & 9.3 \\
\hline 09512403 & 02-01-96 & 1209 & .26 & .71 & .02 & .17 & .07 & 13.4 & 8 & 269 & 290 & 8.4 \\
\hline 09512403 & $02-25-96$ & 2320 & .31 & 1.3 & .06 & .35 & .05 & 1.4 & 24 & 206 & 229 & 8.9 \\
\hline 09512403 & 03-14-96 & 0806 & .25 & .71 & .05 & .4 & .03 & 16.3 & 16 & 195 & 248 & 7.5 \\
\hline 09512403 & 07-06-96 & 2322 & .56 & 7.1 & .09 & .4 & .11 & .83 & 114 & 300 & 297 & 7.7 \\
\hline 09512403 & 07-09-96 & 0418 & .56 & 7.1 & .08 & .5 & .1 & 1.8 & 2 & 196 & 186 & 7.8 \\
\hline 09512403 & $07-25-96$ & 2146 & .41 & 2.7 & .04 & .37 & .08 & 1.5 & 10 & 156 & 169 & 7.1 \\
\hline 09512403 & 01-13-97 & 0520 & .32 & 1.3 & .04 & .5 & .04 & 1.7 & 44 & 135 & 160 & 8.1 \\
\hline 09512403 & 02-27-97 & 1855 & .25 & .71 & .04 & .29 & .03 & 4.4 & 32 & 258 & 259 & 7.1 \\
\hline 09512403 & 08-03-97 & 0742 & .23 & .5 & .02 & .3 & .06 & 1.9 & 25 & 334 & 336 & 6.9 \\
\hline 09512403 & 08-08-97 & 2009 & 0.35 & 1.7 & 0.04 & 0.31 & 0.05 & 1.1 & 5 & 271 & 308 & 7.3 \\
\hline 09512403 & $12-22-97$ & 0129 & .34 & 1.7 & .04 & .28 & .03 & 10.4 & 14 & 599 & 918 & 7.7 \\
\hline 09512403 & 02-04-98 & 0459 & .3 & 1.3 & .05 & .37 & .03 & 6.6 & 24 & 212 & 274 & 7.9 \\
\hline 09513885 & 11-01-95 & 1948 & .56 & 3.6 & .04 & .72 & .21 & .7 & 33 & 17 & 61 & 6.2 \\
\hline 09513885 & 01-31-96 & 2324 & .22 & .49 & .01 & .29 & .06 & 12.2 & 85 & 97 & 111 & 7 \\
\hline 09513885 & 07-09-96 & 0341 & .48 & 2.6 & .05 & 1 & .14 & 1.3 & 117 & 70 & 194 & 6.8 \\
\hline
\end{tabular}


Table 16. Summary data-Continued

\begin{tabular}{|c|c|c|c|c|c|c|c|c|c|c|c|c|c|}
\hline $\begin{array}{c}\text { Station } \\
\text { identifi- } \\
\text { cation } \\
\text { number }\end{array}$ & Date & Time & $\begin{array}{c}\text { Gage } \\
\text { height } \\
\text { (ft) }\end{array}$ & $\begin{array}{c}\text { Dis- } \\
\text { charge } \\
\left(\mathrm{ft}^{3} / \mathrm{s}\right)\end{array}$ & $\begin{array}{l}\text { Storm- } \\
\text { water } \\
\text { flow } \\
\text { (MGD) }\end{array}$ & $\begin{array}{l}\text { Precipi- } \\
\text { tation, } \\
\text { total } \\
\text { (in./ storm) }\end{array}$ & $\begin{array}{c}\text { 5-minute } \\
\text { maximum } \\
\text { precipi- } \\
\text { tation } \\
\text { intensity } \\
\text { (in./5 min) }\end{array}$ & $\begin{array}{c}\text { Total } \\
\text { storm } \\
\text { duration } \\
\text { (hours) }\end{array}$ & $\begin{array}{c}\text { Antece- } \\
\text { dent dry } \\
\text { days }\end{array}$ & $\begin{array}{c}\text { Specific } \\
\text { conduc- } \\
\text { tance } \\
(\mu \mathrm{S} / \mathrm{cm} \text { at } \\
\left.25^{\circ} \mathrm{C}\right)\end{array}$ & $\begin{array}{r}\text { Spec } \\
\text { condt } \\
\text { anc } \\
\text { labora } \\
(\mu S / \mathrm{c} \text { - } \\
25^{\circ}\end{array}$ & $\begin{array}{ll}\text { ific } & \\
\text { uct- } & \\
\text { e, } & \text { p } \\
\text { tory } & \text { w } \\
\text { m at } & \text { ( } \\
\text { C) } & \end{array}$ & $\begin{array}{c}\text { pH, whole } \\
\text { water, field } \\
\text { (standard } \\
\text { units) }\end{array}$ \\
\hline 09513885 & $07-14-96$ & 2218 & .3 & 1 & .01 & .27 & .07 & 1.2 & 3 & 62 & 106 & & 6.5 \\
\hline 09513885 & 01-13-97 & 0434 & .27 & .71 & .03 & .46 & .04 & 7 & 9 & 75 & 80 & & 8.1 \\
\hline 09513885 & $02-27-97$ & 1754 & .26 & .65 & .03 & .42 & .04 & 3.5 & 32 & 72 & 89 & & 6.9 \\
\hline 09513885 & 07-19-97 & 0620 & .23 & .48 & .01 & .16 & .08 & 1.4 & 106 & 356 & 321 & & 5.7 \\
\hline 09513885 & 08-03-97 & 0835 & .21 & .34 & .01 & .26 & .03 & 5.5 & 15 & 123 & 162 & & 6.9 \\
\hline 09513885 & $12-22-97$ & 0123 & .24 & .54 & .03 & .43 & .07 & 8.1 & 14 & 89 & 75 & & 7.4 \\
\hline 09513885 & 02-04-98 & 0633 & .29 & .9 & .03 & .69 & .05 & 7.9 & 24 & 51 & 57 & & 6.5 \\
\hline 09513925 & $11-01-95$ & 1958 & .6 & 5.1 & .09 & .75 & .15 & .7 & 34 & 59 & 114 & & 6.5 \\
\hline 09513925 & 01-31-96 & 2317 & .31 & .98 & .02 & .19 & .07 & 2.1 & 85 & 146 & 132 & & 7 \\
\hline 09513925 & 07-14-96 & 2203 & .54 & 4.1 & .07 & .85 & .19 & .65 & 5 & 42 & 72 & & 7.1 \\
\hline 09513925 & $07-25-96$ & 2113 & .57 & 4.6 & .1 & .57 & .23 & .7 & 10 & 71 & 90 & & 6.3 \\
\hline 09513925 & 01-13-97 & 0430 & .28 & .74 & .03 & .47 & .04 & 7.2 & 91 & 68 & 83 & & 8.1 \\
\hline 09513925 & 02-27-97 & 1756 & .31 & 1 & .04 & .6 & .05 & 4 & 32 & 72 & 99 & & 7.1 \\
\hline 09513925 & 08-03-97 & 0545 & .5 & 4.3 & .07 & .37 & .22 & 2 & 14 & 139 & 155 & & 7.8 \\
\hline 09513925 & 08-09-97 & 0001 & .28 & .7 & .02 & .21 & .02 & 5 & 5 & 131 & 180 & & 7.5 \\
\hline 09513925 & $12-22-97$ & 0121 & .29 & .79 & .03 & .5 & .05 & 8.4 & 14 & 234 & 77 & & 7.6 \\
\hline 09513925 & 02-04-98 & 0438 & .3 & .86 & .03 & .56 & .04 & 7 & 24 & 83 & 69 & & 6.6 \\
\hline $\begin{array}{c}\text { Station } \\
\text { identifi- } \\
\text { cation } \\
\text { number }\end{array}$ & Date & Time & $\begin{array}{l}\text { pH, whole } \\
\text { water, } \\
\text { laboratory } \\
\text { (standard } \\
\text { units) }\end{array}$ & $\begin{array}{c}\text { Water } \\
\text { tem- } \\
\text { perature } \\
\left({ }^{\circ} \mathrm{C}\right)\end{array}$ & $\begin{array}{c}\text { Air } \\
\text { pressure } \\
\text { (mm of } \\
\mathbf{H g})\end{array}$ & $\begin{array}{c}\text { Oxygen, } \\
\text { dissolved } \\
(\mathrm{mg} / \mathrm{L})\end{array}$ & $\begin{array}{l}\text { COD, } \\
\text { high } \\
\text { level } \\
\text { (mg/L) }\end{array}$ & $\begin{array}{c}\text { Calcium, } \\
\text { dissolved } \\
\text { (mg/L as } \\
\text { Ca) }\end{array}$ & $\begin{array}{l}\text { Magne- } \\
\text { sium, } \\
\text { dissolved } \\
\text { (mg/L as } \\
\mathrm{Mg})\end{array}$ & $\begin{array}{l}\text { Sodium, } \\
\text { dissolved } \\
\text { mg/L as } \\
\mathrm{Na})\end{array}$ & $\begin{array}{l}\text { Potas- } \\
\text { sium } \\
\text { (mg/L } \\
\text { as K) }\end{array}$ & $\begin{array}{c}\text { Bicar- } \\
\text { bonate, } \\
\text { whole } \\
\text { water } \\
\text { (mg/L } \\
\text { as } \\
\left.\mathrm{HCO}_{3}\right)\end{array}$ & $\begin{array}{cc}- & \begin{array}{c}\text { Bicar- } \\
\text { e, } \\
\text { bonate, }\end{array} \\
\text { e } & \text { dis- } \\
\text { r } & \text { solved } \\
\text { (mg/L } & \text { as } \\
& \left.\mathrm{HCO}_{3}\right)\end{array}$ \\
\hline 09512162 & $02-26-96$ & 1400 & 8 & 14.5 & 729 & NA & 21 & 46 & 33 & 120 & 4.8 & 181 & 165 \\
\hline 09512162 & 07-26-96 & 0800 & 7.5 & 27.5 & 732 & NA & 29 & 39 & 35 & 130 & 5.7 & 181 & 178 \\
\hline 09512162 & 08-19-96 & 0845 & 8 & 29 & 732 & NA & 35 & 36 & 29 & 120 & 5.5 & 151 & 151 \\
\hline 09512162 & 09-02-96 & 1240 & 7.7 & 32.5 & 729 & NA & 37 & 35 & 23 & 110 & 5.2 & 145 & 145 \\
\hline 09512162 & 01-13-97 & 1415 & 7.3 & 15.5 & 726 & NA & 37 & 18 & 9.3 & 31 & 5.2 & 71 & 68 \\
\hline 09512162 & 02-28-97 & 0840 & 7.9 & 12 & 724 & NA & 23 & 38 & 20 & 65 & 4.3 & 157 & 155 \\
\hline 09512162 & 08-26-97 & 1200 & 7.4 & 27.5 & 731 & 5.1 & 47 & 12 & 3.2 & 10 & 3.7 & 48 & 43 \\
\hline 09512162 & $12-22-97$ & 0940 & 8.1 & 10.5 & 734 & 9.6 & 19 & 43 & 23 & 93 & 4.3 & 174 & 171 \\
\hline 09512162 & 02-04-98 & 1930 & 7.7 & 16.5 & 731 & 8.5 & 11 & 35 & 19 & 100 & 3.8 & 149 & 149 \\
\hline 09512162 & 02-09-98 & 0740 & 7.7 & 12 & 730 & 8.6 & 12 & 20 & 8.6 & 32 & 2.9 & 90 & 90 \\
\hline 09512165 & 04-01-98 & 1130 & 8.3 & 15.5 & 732 & 7.2 & $<10$ & 36 & 19 & 29 & 2.8 & 190 & 188 \\
\hline 09512184 & 11-01-95 & 2022 & 6.8 & 16 & 726 & 11.6 & 310 & 15 & 3.6 & 22 & 3.8 & 95 & 33 \\
\hline 09512184 & 02-01-96 & 1138 & 7 & 15.5 & 727 & NA & 350 & 11 & 2.7 & 14 & 3.4 & 83 & 37 \\
\hline 09512184 & $07-25-96$ & 2125 & 6.7 & 28 & 736 & NA & NA & 29 & 8.3 & 65 & 8.3 & 96 & 59 \\
\hline
\end{tabular}


Table 16. Summary data-Continued

\begin{tabular}{|c|c|c|c|c|c|c|c|c|c|c|c|c|c|}
\hline $\begin{array}{c}\text { Station } \\
\text { identifi- } \\
\text { cation } \\
\text { number }\end{array}$ & Date & Time & $\begin{array}{l}\text { pH, whole } \\
\text { water, } \\
\text { laboratory } \\
\text { (standard } \\
\text { units) }\end{array}$ & $\begin{array}{c}\text { Water } \\
\text { tem- } \\
\text { perature } \\
\left({ }^{\circ} \mathbf{C}\right)\end{array}$ & $\begin{array}{c}\text { Air } \\
\text { pressure } \\
\text { (mm of } \\
\mathrm{Hg})\end{array}$ & $\begin{array}{c}\text { Oxygen, } \\
\text { dissolved } \\
\text { (mg/L) }\end{array}$ & $\begin{array}{l}\text { COD, } \\
\text { high } \\
\text { level } \\
\text { (mg/L) }\end{array}$ & $\begin{array}{c}\text { Calcium, } \\
\text { dissolved } \\
\text { (mg/L as } \\
\text { Ca) }\end{array}$ & $\begin{array}{l}\text { Magne- } \\
\text { sium, } \\
\text { dissolved } \\
\text { (mg/L as } \\
\mathrm{Mg})\end{array}$ & $\begin{array}{c}\text { Sodium, } \\
\text { dissolved } \\
\mathrm{mg} / \mathrm{L} \text { as } \\
\mathrm{Na})\end{array}$ & $\begin{array}{c}\text { Potas- } \\
\text { sium } \\
\text { (mg/L } \\
\text { as K) }\end{array}$ & $\begin{array}{c}\text { Bicar- } \\
\text { bonate, } \\
\text { whole } \\
\text { water } \\
\text { (mg/L } \\
\text { as } \\
\mathrm{HCO}_{3} \text { ) }\end{array}$ & $\begin{array}{c}\text { Bicar- } \\
\text { bonate, } \\
\text { dis- } \\
\text { solved } \\
\text { (mg/L } \\
\text { as } \\
\mathrm{HCO}_{3} \text { ) }\end{array}$ \\
\hline 09512184 & 09-02-96 & 0341 & 7.3 & 27 & 731 & NA & 190 & 17 & 3.5 & 28 & 3.5 & 38 & 27 \\
\hline 09512184 & $11-29-96$ & 0603 & 7.6 & 12 & 725 & NA & 250 & 16 & 3.9 & 15 & 4.4 & 57 & 30 \\
\hline 09512184 & 01-13-97 & 0435 & 6.7 & 11.5 & 727 & NA & 280 & 14 & 3.4 & 18 & 4.5 & 78 & 42 \\
\hline 09512184 & 08-03-97 & 0327 & 6.8 & 28.5 & 730 & 6.5 & 310 & 26 & 6.3 & 62 & 6.7 & 59 & 24 \\
\hline 09512184 & 08-08-97 & 1954 & 6.9 & 28 & 732 & 5.7 & 330 & 14 & 2.5 & 20 & 3.5 & 62 & 29 \\
\hline 09512184 & 02-04-98 & 0614 & 6.8 & 12 & 733 & 9.1 & 120 & 8.3 & 1.4 & 5.3 & 2.3 & 35 & 24 \\
\hline 09512184 & 02-09-98 & 0047 & 7.6 & 12 & 731 & 8.5 & 53 & 7.3 & 1 & 3.5 & 1.3 & 23 & 21 \\
\hline 09512403 & $11-01-95$ & 2027 & 7.2 & 17.5 & 730 & 8.5 & 300 & 19 & 2.5 & 13 & 5.5 & 164 & 34 \\
\hline 09512403 & 02-01-96 & 1209 & 7.9 & 15 & 725 & NA & 640 & 21 & 2.8 & 17 & 5.9 & 443 & 51 \\
\hline 09512403 & $02-25-96$ & 2320 & 7.7 & 14 & 727 & NA & 250 & 18 & 2.5 & 14 & 4.6 & 125 & 31 \\
\hline 09512403 & 03-14-96 & 0806 & 7.5 & 15 & 726 & $\mathrm{NA}$ & 250 & 19 & 2.7 & 17 & 3.9 & 137 & 49 \\
\hline 09512403 & 07-06-96 & 2322 & 7.9 & 29 & 728 & NA & 530 & 23 & 3.5 & 15 & 7.3 & 402 & 44 \\
\hline 09512403 & 07-09-96 & 0418 & 7.8 & 27 & 729 & 5.2 & 280 & 14 & 1.9 & 8.2 & 3.8 & 171 & 33 \\
\hline 09512403 & $07-25-96$ & 2146 & 7.5 & 27.5 & 740 & NA & 250 & 18 & 2.2 & 9.3 & 4.7 & 168 & 48 \\
\hline 09512403 & 01-13-97 & 0520 & 8 & 14 & 731 & NA & 150 & 11 & 2.1 & 11 & 3.2 & 126 & 31 \\
\hline 09512403 & 02-27-97 & 1855 & 7.9 & 15.5 & 720 & 8.8 & NA & 17 & 3 & 17 & 4.9 & 152 & 44 \\
\hline 09512403 & 08-03-97 & 0742 & 7.3 & 28 & 737 & 5.7 & 370 & 34 & 5 & 17 & 7.8 & 77 & 37 \\
\hline 09512403 & 08-08-97 & 2009 & 7.6 & 29 & 733 & 5.7 & 22 & 25 & 3.7 & 18 & 6.1 & 157 & 48 \\
\hline 09512403 & $12-22-97$ & 0129 & 6.8 & 15 & 726 & 5.2 & 160 & 56 & 7.7 & 22 & 12 & 229 & 173 \\
\hline 09512403 & 02-04-98 & 0459 & 8 & 14.5 & 731 & 9.1 & 260 & 23 & 3.2 & 16 & 4.8 & 85 & 45 \\
\hline 09513885 & $11-01-95$ & 1948 & 5.9 & 18 & 731 & 9.5 & 120 & 4.9 & .8 & 2.7 & .8 & 8 & 7 \\
\hline 09513885 & $01-31-96$ & 2324 & 6.1 & 15 & 727 & NA & 380 & 9.2 & 1.7 & 4.9 & 1.7 & 33 & 14 \\
\hline 09513885 & 07-09-96 & 0341 & 6 & 28 & 729 & 6.7 & 260 & 17 & 2.9 & 11 & 2.2 & 18 & 8 \\
\hline 09513885 & 07-14-96 & 2218 & 6.1 & 28.5 & 732 & NA & 210 & 8 & 1.4 & 4.5 & 1.7 & 14 & 12 \\
\hline 09513885 & 01-13-97 & 0434 & 6.2 & 11 & 725 & NA & 170 & 5.7 & 1.1 & 4.3 & 1.2 & 15 & 12 \\
\hline 09513885 & 02-27-97 & 1754 & 6.5 & 12.5 & 715 & 9 & 150 & 6.9 & 1.1 & 4.2 & 1.5 & 28 & 20 \\
\hline 09513885 & 07-19-97 & 0620 & 5.7 & 30 & 728 & 6.2 & 77 & 36 & 4.6 & 13 & 5.5 & 34 & 7 \\
\hline 09513885 & 08-03-97 & 0835 & 6.1 & 29.5 & 732 & 6.7 & 310 & 17 & 2.4 & 6.3 & 3 & 9 & 6 \\
\hline 09513885 & $12-22-97$ & 0123 & 6.5 & 14.5 & 724 & NA & 150 & 4.9 & 1.2 & 5.3 & 1.1 & 16 & 14 \\
\hline 09513885 & 02-04-98 & 0633 & 6.6 & 11.5 & 733 & 10 & 97 & 4.3 & .84 & 2.9 & .79 & 13 & 12 \\
\hline 09513925 & $11-01-95$ & 1958 & 6.7 & 17 & 729 & 9.1 & 150 & 10 & 1.2 & 5.4 & 2 & 30 & 19 \\
\hline 09513925 & $01-31-96$ & 2317 & 6.6 & 14.5 & 726 & 7.3 & 220 & 11 & 1.7 & 5.6 & 2.9 & 49 & 30 \\
\hline 09513925 & 07-14-96 & 2203 & 6.8 & 27 & 732 & NA & 110 & 5.7 & .69 & 2.7 & 1.7 & 25 & 15 \\
\hline 09513925 & $07-25-96$ & 2113 & 7 & 28.5 & 736 & NA & 110 & 9.2 & 1.1 & 3.8 & 2 & 43 & 13 \\
\hline 09513925 & 01-13-97 & 0430 & 6.7 & 11 & 727 & NA & 78 & 7 & 1.1 & 4.3 & 1.9 & 25 & 24 \\
\hline 09513925 & 02-27-97 & 1756 & 7 & 12.5 & 716 & NA & 82 & 8.4 & 1.2 & 4.8 & 2.5 & 42 & 28 \\
\hline 09513925 & 08-03-97 & 0545 & 7.2 & 27 & 734 & 7 & 210 & 16 & 2.1 & 7.4 & 2.6 & 28 & 18 \\
\hline 09513925 & 08-09-97 & 0001 & 6.2 & 28.5 & 731 & 6.4 & 150 & 16 & 2.4 & 13 & 3.5 & 38 & 29 \\
\hline 09513925 & $12-22-97$ & 0121 & 7.4 & 12.5 & 723 & 8.8 & 65 & 5.9 & .98 & 5.2 & 1.6 & 23 & 22 \\
\hline 09513925 & 02-04-98 & 0438 & 7.7 & 11.5 & 735 & 9.8 & 45 & 6.3 & .73 & 4.1 & 1.6 & 24 & 22 \\
\hline
\end{tabular}


Table 16. Summary data-Continued

\begin{tabular}{|c|c|c|c|c|c|c|c|c|c|c|c|c|c|c|}
\hline $\begin{array}{c}\text { Station } \\
\text { identifi- } \\
\text { cation } \\
\text { number }\end{array}$ & Date & Time & $\begin{array}{c}\text { Carbon- } \\
\text { ate, } \\
\text { whole } \\
\text { water } \\
(\mathrm{mg} / \mathrm{Las} \\
\left.\mathrm{CO}_{3}\right)\end{array}$ & $\begin{array}{c}\text { Carbon- } \\
\text { ate, dis- } \\
\text { solved } \\
(\mathrm{mg} / \mathrm{L} \text { as } \\
\left.\mathrm{CO}_{3}\right)\end{array}$ & $\begin{array}{c}\text { Acid } \\
\text { neutral- } \\
\text { izing } \\
\text { capacity } \\
(\mathrm{mg} / \mathrm{L} \text { as } \\
\left.\mathrm{CaCO}_{3}\right)\end{array}$ & $\begin{array}{l}\text { Alkalin- } \\
\text { ity, dis- } \\
\text { solved } \\
\text { (mg/L } \\
\text { as } \\
\mathrm{CaCO}_{3} \text { ) }\end{array}$ & $\begin{array}{c}\text { Alkalin- } \\
\text { ity, } \\
\text { labor- } \\
\text { atory } \\
(\mathrm{mg} / \mathrm{Las} \\
\left.\mathrm{CaCO}_{3}\right)\end{array}$ & $\begin{array}{c}\text { Sul- } \\
\text { fate, } \\
\text { dis- } \\
\text { solved } \\
(\mathrm{mg} / \mathrm{L} \\
\left.\text { as } \mathrm{SO}_{4}\right)\end{array}$ & $\begin{array}{l}\text { Chlor- } \\
\text { ide, dis- } \\
\text { solved } \\
\text { (mg/L as } \\
\text { CI) }\end{array}$ & $\begin{array}{l}\text { Resi- } \\
\text { due, } \\
\text { dis- } \\
\text { solved } \\
\text { at } 180^{\circ} \mathrm{C} \\
\text { (mg/L) }\end{array}$ & $\begin{array}{c}\text { Res- } \\
\text { idue, } \\
\text { total at } \\
105^{\circ} \mathrm{C} \\
(\mathrm{mg} / \mathrm{L})\end{array}$ & $\begin{array}{c}\text { Nitro- } \\
\text { gen, } \\
\text { nitrate } \\
\text { total, } \\
(\mathrm{mg} / \mathrm{L} \\
\text { as N) }\end{array}$ & $\begin{array}{c}\text { Nitro- } \\
\text { gen, } \\
\text { nitrite } \\
\text { total, } \\
\text { (mg/L } \\
\text { as N) }\end{array}$ & $\begin{array}{c}\text { Nitrogen, } \\
\text { nitrate } \\
\text { plus } \\
\text { nitrite, } \\
\mathrm{NO}_{2}+\mathrm{NO}_{3} \\
\text { total } \\
\text { (mg/L as } \\
\mathrm{N} \text { ) }\end{array}$ \\
\hline 09512162 & $02-26-96$ & 1400 & 0 & 8 & 148 & 150 & 152 & 73 & 210 & 648 & 8 & 3.03 & 0.07 & 3.1 \\
\hline 09512162 & $07-26-96$ & 0800 & 0 & 0 & 148 & 146 & 151 & 81 & 230 & 544 & 4 & 1.21 & .09 & 1.3 \\
\hline 09512162 & 08-19-96 & 0845 & 0 & 0 & 124 & 124 & 131 & 66 & 190 & 576 & 8 & .71 & .04 & .75 \\
\hline 09512162 & 09-02-96 & 1240 & 0 & 0 & 119 & 119 & 118 & 59 & 190 & 522 & 12 & .3 & .03 & .33 \\
\hline 09512162 & 01-13-97 & 1415 & 0 & 0 & 58 & 56 & 60 & 37 & 42 & 204 & 10 & .63 & .04 & .67 \\
\hline 09512162 & $02-28-97$ & 0840 & 0 & 0 & 129 & 127 & 130 & 85 & 86 & 408 & 100 & .6 & .04 & .64 \\
\hline 09512162 & $08-26-97$ & 1200 & 0 & 0 & 39 & 35 & 39 & 9.6 & 13 & 116 & 78 & .908 & .062 & .97 \\
\hline 09512162 & $12-22-97$ & 0940 & 0 & 0 & 143 & 140 & 146 & 87 & 130 & 496 & 9 & .277 & .013 & .29 \\
\hline 09512162 & 02-04-98 & 1930 & 0 & 0 & 122 & 122 & 127 & 58 & 140 & 474 & 12 & .975 & .025 & 1 \\
\hline 09512162 & 02-09-98 & 0740 & 0 & 0 & 74 & 74 & 78 & 25 & 40 & 197 & 14 & .926 & .064 & .99 \\
\hline 09512165 & 04-01-98 & 1130 & 2 & 4 & 160 & 160 & 169 & 37 & 18 & 262 & 119 & NA & $<.010$ & .16 \\
\hline 09512184 & $11-01-95$ & 2022 & 0 & 0 & 78 & 27 & 78 & 18 & 25 & 152 & 540 & 1.48 & .12 & 1.6 \\
\hline 09512184 & $02-01-96$ & 1138 & 0 & 0 & 68 & 31 & 56 & 12 & 17 & 111 & 408 & .59 & .1 & .69 \\
\hline 09512184 & $07-25-96$ & 2125 & 0 & 0 & 79 & 48 & 84 & 63 & 95 & 424 & 256 & 1.8 & .2 & 2 \\
\hline 09512184 & 09-02-96 & 0341 & 0 & 0 & 31 & 22 & 29 & 23 & 42 & 182 & 136 & 1.67 & .03 & 1.7 \\
\hline 09512184 & $11-29-96$ & 0603 & 0 & 0 & 47 & 25 & 59 & 27 & 15 & 154 & 340 & 1.53 & .07 & 1.6 \\
\hline 09512184 & 01-13-97 & 0435 & 0 & 0 & 64 & 34 & 62 & 25 & 21 & 150 & 440 & .58 & .09 & .67 \\
\hline 09512184 & 08-03-97 & 0327 & 0 & 0 & 48 & 20 & 118 & 39 & 89 & 373 & 428 & 1.77 & .13 & 1.9 \\
\hline 09512184 & 08-08-97 & 1954 & 0 & 0 & 51 & 24 & 75 & 15 & 27 & 167 & 516 & 1.24 & .063 & 1.3 \\
\hline 09512184 & 02-04-98 & 0614 & 0 & 0 & 29 & 20 & 34 & 7.3 & 6.1 & 77 & 116 & .742 & .068 & .81 \\
\hline 09512184 & 02-09-98 & 0047 & 0 & 0 & 19 & 17 & 25 & 4.3 & 4.4 & 47 & 77 & .604 & .056 & .66 \\
\hline 09512403 & $11-01-95$ & 2027 & 0 & 0 & 135 & 28 & 74 & 16 & 17 & 155 & 960 & 2.52 & .08 & 2.6 \\
\hline 09512403 & $02-01-96$ & 1209 & 0 & 0 & 363 & 42 & 92 & 17 & 21 & 174 & 2,160 & 2.31 & .29 & 2.6 \\
\hline 09512403 & $02-25-96$ & 2320 & 0 & 10 & 103 & 41 & 51 & 14 & 24 & 161 & 562 & 3.54 & .06 & 3.6 \\
\hline 09512403 & 03-14-96 & 0806 & 0 & 0 & 112 & 40 & 75 & 9.9 & 21 & 137 & 712 & 3.17 & .13 & 3.3 \\
\hline 09512403 & $07-06-96$ & 2322 & 2 & 0 & 334 & 36 & 118 & 24 & 21 & 235 & 2,560 & 3.55 & .05 & 3.6 \\
\hline 09512403 & 07-09-96 & 0418 & 0 & 0 & 140 & 27 & 85 & 11 & 10 & 122 & 1,400 & 2.02 & .08 & 2.1 \\
\hline 09512403 & $07-25-96$ & 2146 & 0 & 0 & 138 & 39 & 87 & 10 & 13 & 131 & 860 & 2.04 & .06 & 2.1 \\
\hline 09512403 & 01-13-97 & 0520 & 0 & 0 & 103 & 25 & 101 & 13 & 16 & 94 & 1,000 & 1.22 & .08 & 1.3 \\
\hline 09512403 & $02-27-97$ & 1855 & 0 & 0 & 125 & 36 & 94 & 16 & 25 & 162 & 780 & 2.91 & .19 & 3.1 \\
\hline 09512403 & 08-03-97 & 0742 & 0 & 0 & 63 & 30 & 100 & 39 & 21 & 306 & 368 & 3.2 & .1 & 3.3 \\
\hline 09512403 & 08-08-97 & 2009 & 0 & 0 & 129 & 39 & 91 & 21 & 23 & 225 & 1,190 & 2.84 & 0.059 & 2.9 \\
\hline 09512403 & $12-22-97$ & 0129 & 0 & 0 & 188 & 142 & 187 & 63 & 23 & 1,290 & 125 & .25 & .71 & .96 \\
\hline 09512403 & 02-04-98 & 0459 & 0 & 0 & 70 & 37 & 73 & 22 & 22 & 236 & 304 & 3.4 & .2 & 3.6 \\
\hline 09513885 & $11-01-95$ & 1948 & 0 & 0 & 7 & 6 & 11 & 5.7 & 2.3 & 54 & 62 & .97 & .02 & .99 \\
\hline 09513885 & $01-31-96$ & 2324 & 0 & 0 & 27 & 11 & 25 & 8.5 & 4.2 & 114 & 248 & 1.11 & .29 & 1.4 \\
\hline 09513885 & 07-09-96 & 0341 & 0 & 0 & 15 & 7 & 30 & 35 & 11 & 196 & 104 & 1.58 & .02 & 1.6 \\
\hline 09513885 & $07-14-96$ & 2218 & 0 & 0 & 11 & 10 & 17 & 9.5 & 4.5 & 116 & 90 & 1.48 & .02 & 1.5 \\
\hline
\end{tabular}


Table 16. Summary data-Continued

\begin{tabular}{|c|c|c|c|c|c|c|c|c|c|c|c|c|c|c|}
\hline $\begin{array}{c}\text { Station } \\
\text { identifi- } \\
\text { cation } \\
\text { number }\end{array}$ & Date & Time & $\begin{array}{c}\text { Carbon- } \\
\text { ate, } \\
\text { whole } \\
\text { water } \\
(\mathrm{mg} / \mathrm{L} \text { as } \\
\left.\mathrm{CO}_{3}\right)\end{array}$ & $\begin{array}{c}\text { Carbon- } \\
\text { ate, dis- } \\
\text { solved } \\
(\mathrm{mg} / \mathrm{L} \text { as } \\
\left.\mathrm{CO}_{3}\right)\end{array}$ & $\begin{array}{c}\text { Acid } \\
\text { neutral- } \\
\text { izing } \\
\text { capacity } \\
\text { (mg/L as } \\
\mathrm{CaCO}_{3} \text { ) }\end{array}$ & $\begin{array}{l}\text { Alkalin- } \\
\text { ity, dis- } \\
\text { solved } \\
\text { (mg/L } \\
\text { as } \\
\mathrm{CaCO}_{3} \text { ) }\end{array}$ & $\begin{array}{c}\text { Alkalin- } \\
\text { ity, } \\
\text { labor- } \\
\text { atory } \\
(\mathrm{mg} / \mathrm{Las} \\
\left.\mathrm{CaCO}_{3}\right)\end{array}$ & $\begin{array}{c}\text { Sul- } \\
\text { fate, } \\
\text { dis- } \\
\text { solved } \\
(\mathrm{mg} / \mathrm{L} \\
\left.\text { as } \mathrm{SO}_{4}\right)\end{array}$ & $\begin{array}{l}\text { Chlor- } \\
\text { ide, dis- } \\
\text { solved } \\
\text { (mg/L as } \\
\text { CI) }\end{array}$ & $\begin{array}{c}\text { Resi- } \\
\text { due, } \\
\text { dis- } \\
\text { solved } \\
\text { at } 180^{\circ} \mathrm{C} \\
(\mathrm{mg} / \mathrm{L})\end{array}$ & $\begin{array}{c}\text { Res- } \\
\text { idue, } \\
\text { total at } \\
105^{\circ} \mathrm{C} \\
(\mathrm{mg} / \mathrm{L})\end{array}$ & $\begin{array}{c}\text { Nitro- } \\
\text { gen, } \\
\text { nitrate } \\
\text { total, } \\
\text { (mg/L } \\
\text { as N) }\end{array}$ & $\begin{array}{c}\text { Nitro- } \\
\text { gen, } \\
\text { nitrite } \\
\text { total, } \\
\text { (mg/L } \\
\text { as N) }\end{array}$ & $\begin{array}{c}\text { Nitrogen, } \\
\text { nitrate } \\
\text { plus } \\
\text { nitrite, } \\
\mathrm{NO}_{2}+\mathrm{NO}_{3} \\
\text { total } \\
\text { (mg/L as } \\
\mathrm{N} \text { ) }\end{array}$ \\
\hline 09513885 & 01-13-97 & 0434 & 0 & 0 & 13 & 9 & 14 & 7.1 & 5.5 & 74 & 140 & .55 & .04 & .59 \\
\hline 09513885 & $02-27-97$ & 1754 & 0 & 0 & 23 & 17 & 23 & 7 & 4.3 & 82 & 130 & .87 & .06 & .93 \\
\hline 09513885 & 07-19-97 & 0620 & 0 & 0 & 28 & 6 & 73 & 41 & 12 & 436 & 272 & 3.84 & .062 & 3.9 \\
\hline 09513885 & 08-03-97 & 0835 & 0 & 0 & 7 & 5 & 41 & 16 & 4.9 & 224 & 60 & 2.05 & .052 & 2.1 \\
\hline 09513885 & $12-22-97$ & 0123 & 0 & 0 & 13 & 11 & 17 & 8.3 & 5.3 & 66 & 178 & .476 & .044 & .52 \\
\hline 09513885 & 02-04-98 & 0633 & 0 & 0 & 11 & 10 & 14 & 5.8 & 2.2 & 56 & 64 & .316 & .034 & .35 \\
\hline 09513925 & $11-01-95$ & 1958 & 0 & 0 & 24 & 15 & 34 & 6.2 & 6.7 & 82 & 140 & 1.15 & .05 & 1.2 \\
\hline 09513925 & $01-31-96$ & 2317 & 0 & 0 & 40 & 24 & 45 & 6.1 & 6 & 100 & 180 & 1.07 & .13 & 1.2 \\
\hline 09513925 & 07-14-96 & 2203 & 0 & 0 & 20 & 12 & 28 & 3.6 & 3 & 42 & 166 & 1.08 & .02 & 1.1 \\
\hline 09513925 & $07-25-96$ & 2113 & 0 & 0 & 35 & 11 & 42 & 6.2 & 5.4 & 73 & 270 & 1.17 & .03 & 1.2 \\
\hline 09513925 & 01-13-97 & 0430 & 0 & 0 & 20 & 20 & 23 & 3.7 & 4.6 & 57 & 60 & .87 & .06 & .93 \\
\hline 09513925 & 02-27-97 & 1756 & 0 & 0 & 34 & 23 & 34 & 4.1 & 5.6 & 67 & 130 & .94 & .06 & 1 \\
\hline 09513925 & 08-03-97 & 0545 & 0 & 0 & 23 & 15 & 66 & 9.4 & 10 & 137 & 252 & 1.45 & .049 & 1.5 \\
\hline 09513925 & 08-09-97 & 0001 & 0 & 0 & 31 & 24 & 40 & 9.7 & 15 & 185 & 4 & 1.69 & .11 & 1.8 \\
\hline 09513925 & $12-22-97$ & 0121 & 0 & 0 & 19 & 18 & 21 & 3.8 & 5.5 & 55 & 20 & .819 & .051 & .87 \\
\hline 09513925 & 02-04-98 & 0438 & 0 & 0 & 20 & 18 & 24 & 2.5 & 4.3 & 53 & 54 & .876 & .044 & .92 \\
\hline
\end{tabular}

